\title{
Kinetic, Isotherm and Thermodynamic Studies of the Adsorption of Thymol Blue onto Powdered Activated Carbons from Garcinia cola Nut Shells Impregnated with $\mathrm{H}_{3} \mathrm{PO}_{4}$ and KOH: Non-Linear Regression Analysis
}

\author{
Idris-Hermann Tiotsop Kuete1, Donald Raoul Tchuifon Tchuifon ${ }^{1,2}$, \\ George Nche Ndifor-Angwafor'1, Arnaud Tamo Kamdem³ ${ }^{3}$, Solomon Gabche Anagho, ${ }^{1,4}$ \\ ${ }^{1}$ Materials and Process Engineering Team (MPET), Research Unit of Noxious Chemistry and Environmental Engineering \\ (RUNOCHEE), Department of Chemistry, Faculty of Science, University of Dschang, Dschang, Cameroon \\ ${ }^{2}$ Department of Chemical and Process Engineering, Faculty of Industrial Engineering, University of Douala, Douala, Cameroon \\ ${ }^{3}$ Freiburg Materials Research Center (FMF), University of Freiburg, Freiburg, Germany \\ ${ }^{4}$ Department of Chemistry, Faculty of Science, University of Bamenda, Bambili, Cameroon \\ Email: tchuifondonald@yahoo.fr,sg_anagho@yahoo.com
}

How to cite this paper: Kuete, I.-H.T., Tchuifon, D.R.T., Ndifor-Angwafor, G.N., Kamdem, A.T. and Anagho, S.G. (2020) Kinetic, Isotherm and Thermodynamic Studies of the Adsorption of Thymol Blue onto Powdered Activated Carbons from Garcinia cola Nut Shells Impregnated with $\mathrm{H}_{3} \mathrm{PO}_{4}$ and $\mathrm{KOH}$ : Non-Linear Regression Analysis. Journal of Encapsulation and Adsorption Sciences, 10, 1-27. https://doi.org/10.4236/jeas.2020.101001

Received: February 3, 2020

Accepted: March 28, 2020

Published: March 31, 2020

Copyright () 2020 by author(s) and Scientific Research Publishing Inc. This work is licensed under the Creative Commons Attribution International License (CC BY 4.0).

http://creativecommons.org/licenses/by/4.0/ (c) (i) Open Access

\begin{abstract}
In this work, activated carbons (ACs) prepared by chemical activation of garcinia cola nut shell impregnated with $\mathrm{H}_{3} \mathrm{PO}_{4}\left(\mathrm{CBH}_{2 / 1}\right)$ and $\mathrm{KOH}\left(\mathrm{CBK}_{1 / 1}\right)$ were used to study the kinetics, equilibrium and thermodynamics of the adsorption of thymol blue from aqueous solution. The characterization of ACs showed the BET measurements gave surface area and total pore volume respectively of $328.407 \mathrm{~m}^{2} \cdot \mathrm{g}^{-1}$ and $0.1032 \mathrm{~cm}^{3} \cdot \mathrm{g}^{-1}$ for $\mathrm{CBH}_{2 / 1}$ and $25.962 \mathrm{~m}^{2} \cdot \mathrm{g}^{-1}$ and $0.03 \mathrm{~cm}^{3} \cdot \mathrm{g}^{-1}$ for $\mathrm{CBK}_{1 / 1}$; elemental analysis showed a high percentage of carbon in both ACs. Influence of parameters such as initial $\mathrm{pH}$, contact time, adsorbent mass, initial concentration, ionic strength and the effect of temperature on the removal of thymol blue from aqueous solution were studied in batch mode. The studies showed that equilibrium adsorption was attained after 60 minutes for the two ACs, adsorption capacity increased with increasing concentration of thymol blue, and maximum adsorption capacity was obtained at an acidic environment with $\mathrm{pH}$ 2. Avrami's non-linear kinetic expression was the best suited for describing the adsorption kinetics of thymol blue onto ACs, while equilibrium data showed that the three-parameter isotherms better described the adsorption process since $\mathrm{R}^{2}>0.96$, and the error functions were lowest for all of them. Maximum adsorption capacity values
\end{abstract}


obtained using the three-parameter Fritz-Schlunder equation were 32.147 $\mathrm{mg} \cdot \mathrm{g}^{-1}$ for $\mathrm{CBH}_{2 / 1}$ and $67.494 \mathrm{mg} \cdot \mathrm{g}^{-1}$ for $\mathrm{CBK}_{1 / 1}$. The values of the model parameters $g$ and $\mathrm{m}_{\mathrm{FS}}$ respectively, obtained using the Redlich-Peterson and Fritz-Schlunder III isotherms below 1, showed that the adsorption of thymol blue by the ACs occurred on heterogeneous surfaces. Thermodynamic analyses of the data of the adsorption of thymol blue onto ACs revealed that the adsorption process was temperature dependent, endothermic and spontaneous.

\section{Keywords}

Garcinia Cola Nut Shell, Chemical Activation, Elemental Analysis, Non-Linear Regression, Adsorption Isotherms, Adsorption Kinetic Models

\section{Introduction}

The intensive industrialization considered as key to economic development, which started in the last century is at the origin of the proliferation of various pollutants in the environment, and most of them are difficult to eliminate [1]. The wastes resulting from industrial activities represent a danger to man and his environment, due to their very low biodegradability and the slowness of their elimination [1]. The global increase in water pollution has increased awareness among the public, and more attention is being focused on combating the problem [2].

Conventional methods are being used to remove pollutants from wastewater, some examples of which are chemical precipitation, electrodialysis, filtration, reverse osmosis, electrochemical treatment, ion exchange and adsorption onto activated carbons. In comparison with other methods, adsorption is one of the most widely used techniques for the removal of pollutant because it is cost-effective, it is simple in design and implementation and it has a high removal capacity [3]. Also, the adsorption-based treatment with suitable adsorbent material offers high performance and selectivity, and it produces little or no harmful by-products. Adsorption is widely used for removing both organic and inorganic pollutants from contaminated water [4].

Pollutants such as pesticides, phenolic derivatives, heavy metals, and dyes have been identified as having harmful effects on humans, and they also contribute to the destruction of the environment [5]. Of these pollutants, dyes are organic compounds that are particularly dangerous to the environment [6]. About 40,000 dyes and pigments have been listed, and they consist of more than 7000 different chemical structures [7], of which about 10,000 of them are among the various commercial dyes and pigments, and over $7 \times 10^{5}$ tons are produced annually [8]. Dyes are used in multiple sectors of the economy, some examples of which are: in changing the colors textiles, paper, paint, cosmetics, drinks, and as food additives. Many of these dyes are carcinogenic, mutagenic, genotoxic 
and teratogenic and they are also toxic to human beings, fish species, and microorganisms [9]. The majority of these pollutants are not biodegradable and can constitute risk factors to our health, as well as being a nuisance to the environment. The presence of these pollutants in water, even at very low concentrations is very undesirable because it is highly visible. In fact, the presence of dyes in flowing streams causes a high reduction in the activity of photosynthesis [10].

Thymol blue is an example of such a dye. It is used as a $\mathrm{pH}$ indicator in analytical chemistry. When inhaled it leads to irritation of the respiratory tract, or when it gets in contact with the skin, it is very painful [11]. These effects have become a major concern to the society. For this reason, many studies have focused on the use of depollution techniques to eliminate pollutants from wastewaters. The majority of these techniques are very expensive and difficult to implement especially when they are applied to effluents of high flow rates and having low concentrations of pollutants.

Adsorption has proved to be a more effective and cheaper process, and its equipment is easy to implement [1]. However, the choice of adsorbent remains a major worry because most adsorbent materials such as alumina, zeolites, activated clays, and silica gels are also used as catalyst support materials [12]. Therefore, activated carbons are the most commonly used adsorbents because they contain large surface areas, well-developed porosity and contains various functional groups on their surfaces.

Activated carbons prepared by chemical activation of lignocellulosic materials have been used for the adsorption of dyes, various organic compounds and antipyretic/analgesic drugs [13] [14] [15]. The advantage of chemical activation is that the pyrolysis stage of the synthesis is achieved at low temperature, thereby greatly reducing the cost of fabrication. Over the last few years, much interest has been shown by researchers on the technique of adsorption, and they have produced low cost activated carbons from lignocellulosic materials which are abundant agricultural wastes, to remove organic compounds, metals and dyes from solutions of waste streams. The costs of activated carbons prepared from lignocellulosic materials are very low compared to the cost of commercial activated carbons [9]. Many activated carbons have been produced from various carbonaceous materials resulting from agricultural wastes such as coconut shells [9], cola nut shells [13], rice and coffee husks [14], Ayous sawdust and Cucurbitaceous peelings [15], hibiscus sabdariffa and stalk biomass [16]. In this work, we will prepare ACs using shells of Garcinia cola (bitter cola) nuts [17], due to the availability and cost free of the material as well as its high carbon content. However, little or no work has been reported on the production of activated carbons using the garcinia cola nut shells.

The aim of this work was to evaluate the adsorption properties of activated carbons prepared from garcinia cola nut shells impregnated by $\mathrm{H}_{3} \mathrm{PO}_{4}$ and $\mathrm{KOH}$ for the removal of thymol blue from aqueous solution. Thermodynamics studies were carried out, and the experimental data were analyzed using the two-parameter 
non-linear regressions kinetics, and two- to five-parameter non-linear isotherm models.

\section{Materials and Methods}

\subsection{Chemicals: Adsorbate (Thymol Blue)}

The adsorbent used in this study was thymol blue, which is an anionic dye. Thymol blue, also called thymol sulphonephthalein is a brownish-green or reddish-brown crystalline powder that is used as a $\mathrm{pH}$ indicator and for biological activities. It is insoluble in water, but soluble in alcohol and dilute alkali solutions. Its colour changes from red to yellow at $\mathrm{pH} 1.2-2.8$ and from yellow to blue at $\mathrm{pH} 8.0$ - 9.6. A stock of $500 \mathrm{mg} \cdot \mathrm{L}^{-1}$ of thymol blue was prepared by dissolving $125 \mathrm{mg}$ in $100 \mathrm{~mL}$ of dilute alkali solution $\left(\mathrm{Na}^{+}+\mathrm{HO}^{-}\right)$using distilled water and then completing to $250 \mathrm{~mL}$. Working solutions of various concentrations were freshly prepared from this stock solution. $\mathrm{HCl}$ or $\mathrm{NaOH}$ of concentration $0.1 \mathrm{~mol} \cdot \mathrm{L}^{-1}$ was used to adjust the initial $\mathrm{pH}$ of the solution. $\mathrm{NaCl}$ was used to study the influence of ionic strength on the adsorption process

\subsection{Absorbents}

The ACs used had been prepared using optimized experimental conditions by chemical activation of garcinia cola (bitter cola) nut shells. The $\mathrm{AC} \mathrm{CBH}_{2 / 1}$ was prepared by activating garcinia cola nut shells with $\mathrm{H}_{3} \mathrm{PO}_{4}$ in a ratio $2 / 1$, while $\mathrm{CBK}_{1 / 1}$ was prepared by activating with $\mathrm{KOH}$ in a ratio $1 / 1$. The chemical activation was followed by calcination in a furnace set at $400^{\circ} \mathrm{C}$ for 1 hour and a heating rate of $5{ }^{\circ} \mathrm{C} \cdot \mathrm{min}^{-1}$ as described by Idris-Hermann et al. [17].

\subsection{Characterizations}

Ultimate analyses of raw material and ACs were performed for determining the $\mathrm{C}, \mathrm{H}, \mathrm{N}$, and $\mathrm{S}$ content using CHNSO elemental analyses from HEKAtech CHNS Analyzer. The oxygen content was calculated by the difference on $100 \%$. Textural analysis was performed by $\mathrm{N}_{2}$-sorption measurements at $77 \mathrm{~K}$ using multipoint porosimeter automatic analyzer (Sorptomatic 1990, Porotec, $\mathrm{GmbH}$ ), system ADP2005 Extended Report software using to calculated BET-surface area, total pore volume and pore size..., with a relative pressure range of $0.05<$ $P / P_{0}<0.25$, with an overnight pretreatment of $150^{\circ} \mathrm{C}$ for 5 hours. Total pore volume ( $\left.V_{\text {tot }}\right)$ was estimated to be the liquid volume of $\mathrm{N}_{2}$ at the high relative pressure $P / P_{0}=0.95$. The micropore volume ( $V_{\text {micro }}$ ) was obtained using the D-R method and average pore diameter $\left(D_{P}\right)$ was calculated from $D_{P}=4 V_{T} / S_{\mathrm{BET}}[18]$. The micropore size distribution parameter was calculated according to the simplified equation of the Horvath-Kawazone (HK) [19].

The BET specific surface area $\left(S_{\mathrm{BET}}\right)$ was calculated using the equation below:

$$
S_{\mathrm{BET}}=\frac{V_{m} \cdot N_{A} \cdot \sigma}{m \cdot V_{M}}
$$


where $V_{m}$ is the volume occupied by a monolayer, $N_{A}$ is the Avogadro constant $6.023 \times 10^{23} \mathrm{~mol}^{-1}, \sigma$ is the surface occupied by the $\mathrm{N}_{2}$ molecule $\left(16.2 \AA^{2}\right)$; $\mathrm{m}$ is the mass of the sample $(\mathrm{g})$ and $V_{M}$ is the molar volume of $\mathrm{N}_{2}\left(22414 \mathrm{~cm}^{3} \cdot \mathrm{mol}^{-1}\right)$.

In our earlier work, Idris-Hermann et al. [17], the different ACs had been characterized by proximate analysis, bulk density, $\mathrm{pH}$ of zero point charge $\left(\mathrm{pH}_{\mathrm{zpc}}\right)$, methylene blue number, iodine number, surface functional groups, Fourier transform infra-red spectroscopy (FTIR), scanning electron microscopy (SEM), and power X-ray diffraction (XRD).

\subsection{Batch Adsorption Experiments}

Adsorption experiments were carried out by mechanical agitation at ambient temperature and constant agitation speed of $200 \mathrm{rpm}$. For each run, $20 \mathrm{~mL}$ of thymol blue dye solution of known initial concentration varying between 40 and $90 \mathrm{mg} \cdot \mathrm{L}^{-1}$ was treated with $50 \mathrm{mg}$ each of the $\mathrm{ACs} \mathrm{CBH}_{2 / 1}$ and $\mathrm{CBK}_{1 / 1}$, and at $\mathrm{pH}=2$. After agitation, the solution was filtered using Whatman $\mathrm{N}^{\circ} 1$ filter paper and the filtrate analyzed to obtain the residual concentration of thymol blue using a UV/Vis spectrophotometer (Jenway, model 6715). Similar measurements were carried out by varying the $\mathrm{pH}$ of the solution, adsorbents doses, ionic strength and the initial concentration of the solution. Absorbance values were determined at a maximum wavelength $\left(\lambda_{\max }\right)$ of $435 \mathrm{~nm}$. The percentage removal $(\% R)$ of dye, and the amount of dye adsorbed $\left(Q_{e}\right)$ were calculated using the following expressions:

$$
\begin{gathered}
\% R=\frac{C_{0}-C_{e}}{C_{0}} \times 100 \\
Q_{e}=\frac{C_{0}-C_{e}}{m} \times V
\end{gathered}
$$

$C_{0}$ is the initial concentration of the dye, $C_{e}$ is the concentration of the dye at the time $t, V$ is the volume of the adsorbate solution, and $\mathrm{m}$ is the mass of the adsorbent.

\subsubsection{Effect of Initial $\mathrm{pH}$}

To determine the effect of $\mathrm{pH}$, the adsorption of thymol blue by the ACs were investigated over a $\mathrm{pH}$ range of 2 to 7 at ambient temperature. For each adsorbent, $50 \mathrm{mg}$ was treated with $20 \mathrm{~mL}$ of aqueous solution of $50 \mathrm{mg} \cdot \mathrm{L}^{-1}$ of thymol blue dye. The initial $\mathrm{pH}$ of the solution was adjusted by adding $\mathrm{HCl}$ or $\mathrm{NaOH}$ solution.

\subsubsection{Effect of Contact Time}

To determine the effect of agitation time on the adsorption process, $50 \mathrm{mg}$ of ground adsorbent was agitated in a $20 \mathrm{~mL}$ solution of thymol blue of initial concentration $50 \mathrm{mg} \cdot \mathrm{L}^{-1}$ for different contact times, varying between 0 and 105 minutes. After each contact time $t$, the solution was rapidly filtered and the residual concentration of thymol blue, $C_{e}$ determined by UV/Vis spectrophotome- 
ter. The amount $\left(Q_{e}\right)$ of thymol blue adsorbed was calculated using Equation (3).

\subsubsection{Effect of Amount of Adsorbent}

In this set of experiments, different masses of the adsorbents $30,50,70,90,110$, 130,150 and $170 \mathrm{mg}$ were treated with $20 \mathrm{~mL}$ solution of thymol blue of initial concentration $50 \mathrm{mg} \cdot \mathrm{L}^{-1}$ at the optimum time obtained from the effect of contact time experiments and the optimum $\mathrm{pH}$ obtained from the effect of $\mathrm{pH}$ experiments.

\subsubsection{Effect of Ionic Strength}

To determine the effect of ionic strength on the adsorption process, $50 \mathrm{mg}$ of each adsorbent was agitated in a $20 \mathrm{~mL}$ solution of thymol blue at $\mathrm{pH} 2$ of initial concentration $50 \mathrm{mg} \cdot \mathrm{L}^{-1}$ containing the salt, $\mathrm{NaCl}$ of concentrations ranging between 0.01 and $0.06 \mathrm{~mol} \cdot \mathrm{L}^{-1}$. At equilibrium time ( 1 hour), the solution was rapidly filtered and the residual concentration of thymol blue determined by spectrophotometer. The amount $\left(Q_{e}\right)$ of thymol blue adsorbed was calculated.

\subsubsection{Kinetics of Adsorption Studies}

To deduce the controlling mechanisms for the adsorption of thymol blue onto the ACs, data from the kinetics experiments were analyzed using the different non-linear kinetic models presented in Table 1 below.

Table 1. Non-linear forms of kinetic models.

\begin{tabular}{lll}
\hline Kinetic Models & Non-Linear Forms & $\begin{array}{c}\text { Equation } \\
\text { Number }\end{array}$ \\
\hline$\frac{\mathrm{d} Q_{t}}{\mathrm{~d} t}$ & $=K_{1}\left(Q_{e}-Q_{t}\right)$ & References \\
Pseudo-First Order: & $Q_{t}=Q_{e}\left(1-\mathrm{e}^{-K_{t} t}\right)$ & \\
$\mathrm{d} Q_{t}$ & $\mathrm{~d} t$ & $=K_{2}\left(Q_{e}-Q_{t}\right)^{2}$
\end{tabular}




\subsubsection{Adsorption Isotherm Studies}

To study the equilibrium of the adsorption of thymol blue onto the ACs, data from the equilibrium experiments were analyzed using the following two- to five-parameter, non-linear equilibrium models as presented in Table 2 below.

Table 2. Non-linear forms of two, three, four and five parameter isotherms models.

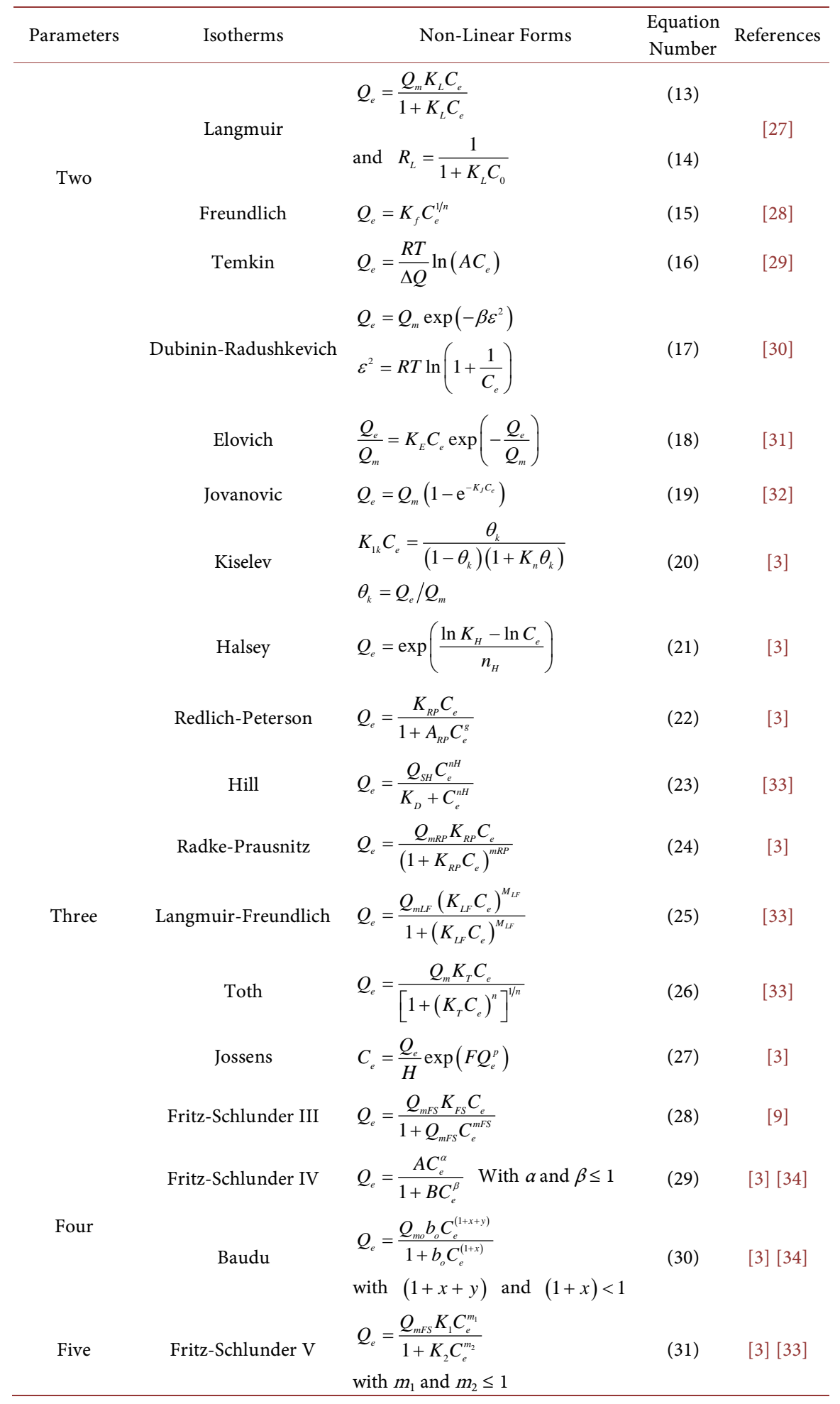




\subsubsection{Non-Linear Regression Analysis}

In this study, non-linear regression was applied using Microsoft Excel Solver function and using Origin Pro 9, 64 bit for fitting the curve. The best fit for experimental data was determined from the coefficient of determination $\left(R^{2}\right)$, residual root mean square error (RMSE), Chi-square test $\left(\chi^{2}\right)$, Sum Square of Errors (ERRSQ), Hybrid Fractional Error Function (HYBRID), Average Relative Error (ARE), Marquardt's Percent Standard Deviation (MPSD), Sum of Absolute Errors (EABS). More detailed definitions of the error functions and statistical comparison values are presented in Table 3.

\subsubsection{Thermodynamic Studies}

The effect of temperature on the adsorption of thymol blue dye onto the ACs was evaluated from thermodynamic studies. $20 \mathrm{~mL}$ of thymol blue solution of concentration $50 \mathrm{mg} \cdot \mathrm{L}^{-1}(\mathrm{pH}=2)$ was placed in contact with $50 \mathrm{mg}$ each of AC in a polypropylene flask and placed on a magnetic stirrer/heater and heated with stirring for the equilibrium time 1 hour, at temperatures of $35^{\circ} \mathrm{C}, 45^{\circ} \mathrm{C}, 55^{\circ} \mathrm{C}$ and $65^{\circ} \mathrm{C}(308,318,328$ and $338 \mathrm{~K})$. After the equilibrium time, the concentration of the remaining thymol blue was determined by spectrophotometry, and the maximum amount adsorbed calculated from Equation (3). The thermodynamic quantities, change in Gibbs free energy $\left(\Delta G^{0}\right)$, enthalpy change $\left(\Delta H^{\oplus}\right)$ and entropy change $\left(\Delta S^{0}\right)$ were calculated.

Table 3. Error functions and their equations.

\begin{tabular}{|c|c|c|c|}
\hline Error Function & Abbreviation & Formula & References \\
\hline $\begin{array}{c}\text { Residual Root } \\
\text { Mean Square Error }\end{array}$ & RMSE & $\sqrt{\frac{1}{n-2} \sum_{i=1}^{N}\left(Q_{e, e x p}-Q_{e, c a l}\right)^{2}}$ & [35] \\
\hline Chi-Square Test & $x^{2}$ & $\sum_{i=1}^{N} \frac{\left(Q_{e, e x p}-Q_{e, c a l}\right)^{2}}{Q_{e, c a l}}$ & [35] \\
\hline Sum Square of Errors & ERRSQ & $\sum_{i=1}^{N}\left(Q_{e, e \times p}-Q_{e, c a l}\right)_{i}^{2}$ & [35] \\
\hline $\begin{array}{l}\text { Hybrid Fractional } \\
\text { Error Function }\end{array}$ & HYBRID & $\frac{100}{N-p} \sum_{i=1}^{N}\left[\frac{\left(Q_{e, i, e x p}-Q_{e, i, c a l}\right)^{2}}{Q_{e, i, e x p}}\right]$ & [33] \\
\hline Average Relative Error & ARE & $\frac{100}{N} \sum_{i=1}^{N}\left|\frac{Q_{e, i, c a l}-Q_{e, i, e \times p}}{Q_{e, i, e \times p}}\right|$ & [33] \\
\hline $\begin{array}{l}\text { Marquardt's Percent } \\
\text { Standard Deviation }\end{array}$ & MPSD & $100{\sqrt{\frac{1}{N-p} \sum_{i=1}^{N}\left(\frac{Q_{e, e x p}-Q_{e, c a l}}{Q_{e, e x p}}\right)^{2}}}^{2}$ & [33] \\
\hline Sum of Absolute Errors & EABS & $\sum_{i=1}^{N}\left|Q_{e, e \times p}-Q_{e, c a l}\right|_{i}$ & [35] \\
\hline Coefficient of Determination & $R^{2}$ & $\frac{\sum_{i=1}^{N}\left(Q_{e, c a l}-Q_{\text {mexp }}\right)^{2}}{\sum_{i=1}^{N}\left(Q_{e, c a l}-Q_{\text {mexp }}\right)^{2}+\left(Q_{e, c a l}-Q_{\text {mexp }}\right)^{2}}$ & [33] \\
\hline
\end{tabular}




\section{Results and Discussion}

\subsection{Textural Characterization of the Adsorbents}

Textural characteristics of all ACs were studied. As it can be observed, $\mathrm{CBK}_{1 / 1}$ $25.962 \mathrm{~m}^{2} \cdot \mathrm{g}^{-1}$ gave the lower value of $\mathrm{S}_{\mathrm{BET}}$ compared to $\mathrm{CBH}_{2 / 1} 328.407 \mathrm{~m}^{2} \cdot \mathrm{g}^{-1}$ calculated by Equation (1). The lower porosity of $\mathrm{CBK}_{1 / 1}$ is confirmed by the higher value of average pore diameter $4.622 \mathrm{~nm}$, while $\mathrm{CBH}_{2 / 1}$ shows $D_{p}$ value of $1.257 \mathrm{~nm}$ smaller than $2.0 \mathrm{~nm}$. However, the $V_{\text {micropores }}$ of $\mathrm{CBH}_{2 / 1}$ is higher than that of $\mathrm{CBK}_{1 / 1}$, which corroborates the microporous characteristic of $\mathrm{CBH}_{2 / 1}$. Total pore volume of $\mathrm{CBH}_{2 / 1} 0.1032 \mathrm{~cm}^{3} \cdot \mathrm{g}^{-1}$ was higher than that of the $\mathrm{CBK}_{1 / 1}$, of $0.03 \mathrm{~cm}^{3} \cdot \mathrm{g}^{-1}$.

The values of total pore volume and BET surface area upon $\mathrm{H}_{3} \mathrm{PO}_{4}$ activation are larger because $\mathrm{H}_{3} \mathrm{PO}_{4}$ prevents the accumulation of tars on the surface of the carbon. Also, according to pore evolution theory, hydrogen and oxygen compounds in the lignocellulosic material are removed in the form of volatiles materials during decomposition. These volatiles diffuse out of the carbon matrix, leading to the development of pores.

The results obtained by scanning electron microscopy (SEM), power X-ray diffraction (XRD) had been presented in our former work, Idris-Hermann et al. [17].

\subsection{Elemental Analysis}

The elemental composition (CHNS) of the raw material (CB) and the two ACs were studied and the results are presented in Table 4 below. It was obvious from the table that $\mathrm{H}_{3} \mathrm{PO}_{4}$ and $\mathrm{KOH}$ used as activating agents have significant influence in producing activating carbons with high ratios of $\mathrm{C} / \mathrm{H}$ and $\mathrm{C} / \mathrm{N}$. As expected, the ACs have much higher contents of carbon and lower contents of oxygen and hydrogen compared to the initial raw material. As a matter of fact, the chemical activation during the heat treatment may accelerate the chemical changes in carbonaceous material and enable the removal of volatile compounds. This could be attributed to the fact that $\mathrm{H}_{3} \mathrm{PO}_{4}$ and $\mathrm{KOH}$ selectively stripe $\mathrm{H}$ and $\mathrm{O}$ away from the garcinia cola nutshells as $\mathrm{H}_{2} \mathrm{O}$ and $\mathrm{H}_{2}$ rather than $\mathrm{CO}, \mathrm{CO}_{2}$ or hydrocarbons [36] [37]. Therefore, the carbonaceous material becomes richer in carbon. However, elemental analyses of the activated carbons indicate the absence of sulphur for all of them.

Table 4. Elemental composition analysis.

\begin{tabular}{ccccccccc}
\hline Materials & $\mathrm{C} \%$ & $\mathrm{H} \%$ & $\mathrm{~N} \%$ & $\mathrm{~S} \%$ & $\mathrm{O} \%$ (diff) & Weight & $\mathrm{C} / \mathrm{H}$ & $\mathrm{C} / \mathrm{N}$ \\
\hline $\mathrm{CB}$ & 53.375 & 4.68 & 1.424 & 0 & 37.475 & 3.046 & 11.405 & 37.482 \\
$\mathrm{CBH}_{2 / 1}$ & 72.023 & 3.177 & 2.125 & 0 & 19.645 & 3.03 & 22.67 & 33.893 \\
$400^{\circ} \mathrm{C}$ & & & & & & & & \\
$\mathrm{CBK}_{1 / 1}$ & 71.877 & 3.874 & 2.133 & 0 & 19.348 & 2.768 & 18.554 & 33.698 \\
$400^{\circ} \mathrm{C}$ & & & & & & & & \\
\hline
\end{tabular}




\subsection{Batch Adsorption Studies}

\subsubsection{Effect of Initial pH}

The effect of initial $\mathrm{pH}$ on the adsorption of thymol blue dye by the two ACs was studied by varying the initial $\mathrm{pH}$ of the thymol blue solution. The result is shown in Figure 1. According to this figure, the removal of dye from aqueous solution is highly dependent on the $\mathrm{pH}$ of the solution. In Figure 1, the results show that, the maximum capacity of adsorption is obtained at $\mathrm{pH}=2$ and favoured for $\mathrm{pH}$ $<\mathrm{pH}_{\mathrm{PZC}}$. The $\mathrm{pH}$ at the point of zero chage, $\mathrm{pH}_{\mathrm{PZC}}$ was obtained for the two ACs as 7.751 for $\mathrm{CBH}_{2 / 1}$ and 8.324 for $\mathrm{CBK}_{1 / 1}$ [17]. When the $\mathrm{pH}$ increases, the capacity of adsorption decreases from 14.809 to $3.684 \mathrm{mg} \cdot \mathrm{g}^{-1}$ and 15.476 to 2.514 $\mathrm{mg} \cdot \mathrm{g}^{-1}$ for $\mathrm{CBH}_{2 / 1}$ and $\mathrm{CBK}_{1 / 1}$ respectively. This can be explained by the fact that, when the $\mathrm{pH}$ of solution is lower than the $\mathrm{pH}_{\mathrm{PZC}}$, more protons will be available for protonating the surface of the ACs, thereby increasing the electrostatic attraction between the positively charged adsorbent sites and negatively charged or nucleophilic character of thymol blue. This phenomenon can also be explained by the fact that at $\mathrm{pH}=2$, the positive charge dominates on the surface of the adsorbents, hence increasing the existing electrostatic attraction between the positively charged surface of the adsorbents and negatively charged thymol blue molecules. Thymol blue dye carries a negative charge on its sulfonic $\left(-\mathrm{SO}_{3}^{-}\right)$ functional group. They are equally attracted by positively charged adsorbent site at lower $\mathrm{pH}$.

However, increasing $\mathrm{pH}$ above $\mathrm{pH}_{\mathrm{PZC}}$ the thymol blue becomes more soluble and the negative charges on the surface of the ACs increase the electrostatic force of repulsion between adsorbate (sulfonic functional group of thymol blue)

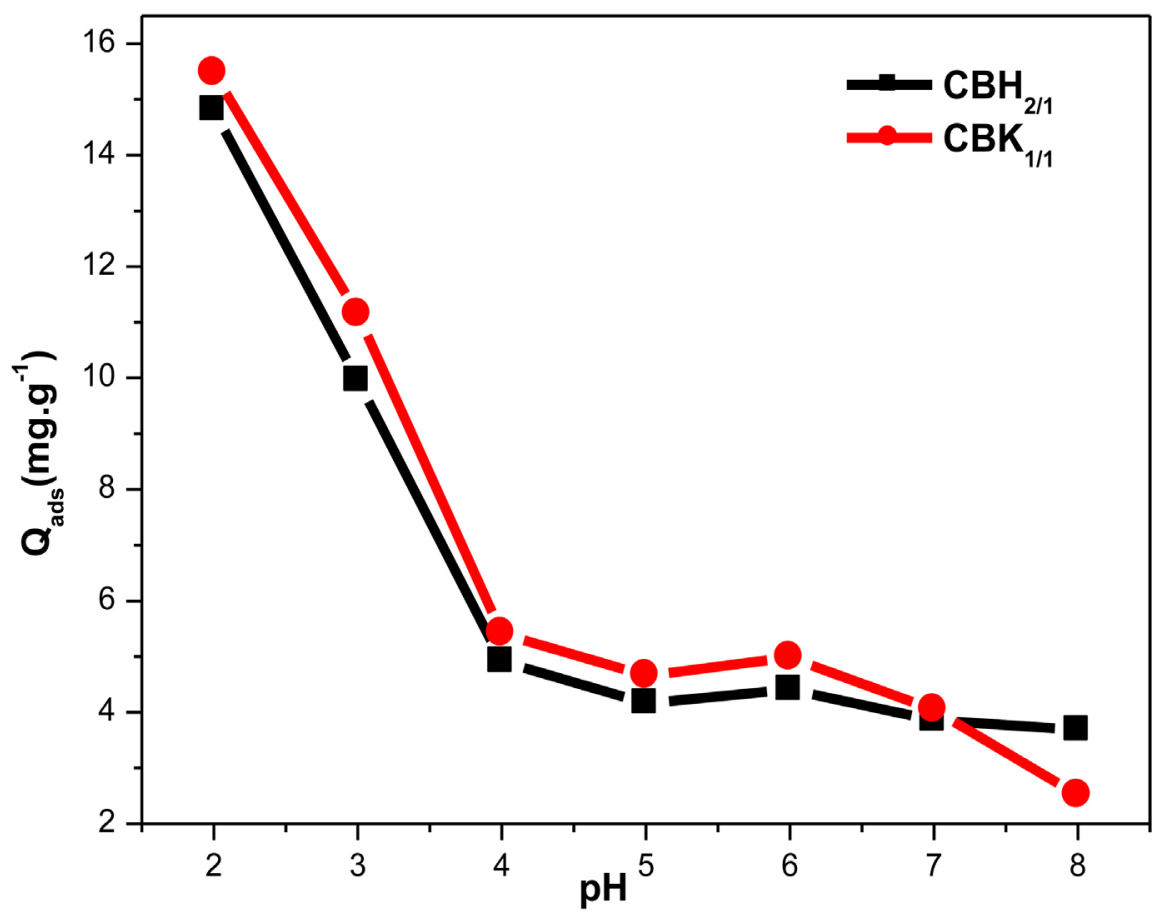

Figure 1. Effect of $\mathrm{pH}$ of solution on the adsorption of thymol blue. 
and $-\mathrm{OH}$ groups of the ACs surface due to the increased concentration of the hydroxide ions. The electrostatic force of repulsion between thymol blue and adsorbent is at the origin of the decreasing capacity of adsorption. A similar result was obtained from the adsorption of amaranth red by pineapple peelings and coconut shells ${ }^{1}$.

\subsubsection{Effect of Contact Time}

The effect of contact time on the adsorption of thymol blue is given in Figure 2 below. The figure shows the evolution of the adsorption capacity of thymol blue with time of contact at ambient temperature. It can be observed that, the adsorption process took place in three phases. Rapid adsorption of thymol blue took place in the first 5 minutes for the two activated carbons. This is explained as follows: at the start of the adsorption process, all the vacant sites on the adsorbent were completely available and the thymol blue molecules were fast attached. The same tendency had been obtained by Ndifor-Angwa for and others when they adsorbed amaranth red onto treated and untreated lignocellulosic materials [1]. Thereafter, the rate of adsorption deceased gradually with the progress of adsorption within 5 to 60 minutes for the two adsorbents, and reached equilibrium in about 60 minutes. The adsorption capacity at these equilibrium points are $14.974 \mathrm{mg} \cdot \mathrm{g}^{-1}$ for $\mathrm{CBH}_{2 / 1}$ and $15.839 \mathrm{mg} \cdot \mathrm{g}^{-1}$ for $\mathrm{CBK}_{1 / 1}$. This can be explained by the fact that the available sites for adsorption have been greatly reduced by the thymol blue molecules already attached there. Also, the already adsorbed molecules tend to repel any other approaching molecules as they are similarly charged, thereby reducing the rate of adsorption. The adsorption process can be attributed to aromatic condensation due to $\pi-\pi$ interactions between thymol

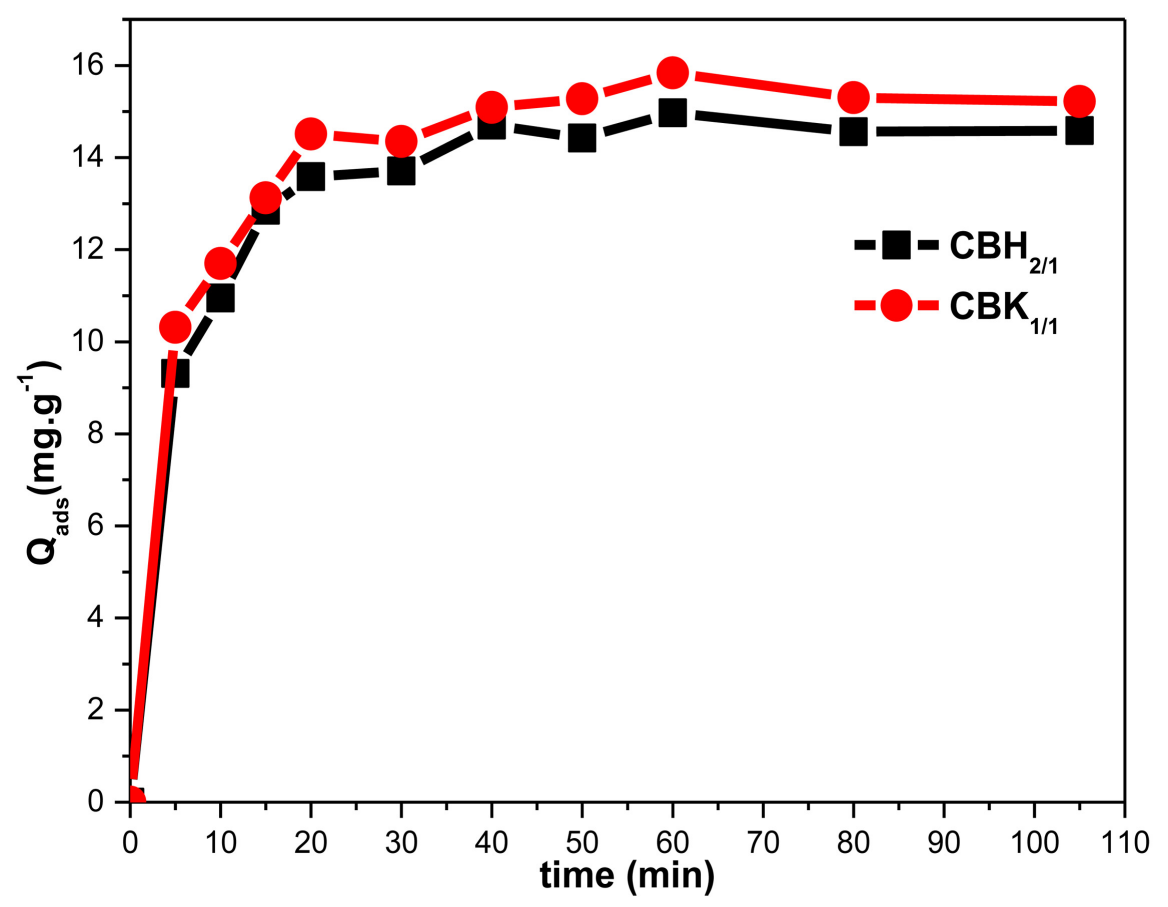

Figure 2. Effect of contact time on the adsorption of thymol blue. 
blue molecules and the surface of the adsorbent. During the aromatic condensation, it is possible that surface functional groups of adsorbent do not occupy the entire nucleophilic sites of thymol blue. Figure 2 also shows that there is no significant change in the rate of adsorption of thymol blue after equilibrium time. This corresponds to the third phase, which lies between 60 and 105 minutes, in which for $\mathrm{CBH}_{2 / 1}$ and $\mathrm{CBK}_{1 / 1}$ the adsorption capacities are almost constant with time.

\subsubsection{Effect of Adsorbent Dosage}

The effect of adsorbent dosage on the removal of thymol blue was studied and the results of this study are shown in Figure 3 below. In this figure, the percentage removal of thymol blue by $\mathrm{CBH}_{2 / 1}$ and $\mathrm{CBK}_{1 / 1}$ increased as the adsorbent dosage increased. The removal percentage of thymol blue increased from 63.519 to 76.623 and 66.445 to 83.058 for $\mathrm{CBH}_{2 / 1}$ and $\mathrm{CBK}_{1 / 1}$ respectively. This is because an increase in adsorbent mass leads to an increase in surface area, and hence an increase in the number of available adsorption sites for thymol blue to occupy during the adsorption process [38]. A similar trend was reported in Hameed et al. [39] for the adsorption of chromotrope dye onto activated carbons obtained from the seeds of various plants.

\subsubsection{Effect of Initial Concentration}

The effect of initial concentration on the adsorption of thymol blue was investigated and the results are show in Figure 4 below. In Figure 4, we observe that the quantity of thymol blue adsorbed at equilibrium increases from 10.519 to $34.400 \mathrm{mg} \cdot \mathrm{g}^{-1}$ and 10.893 to $34.681 \mathrm{mg} \cdot \mathrm{g}^{-1}$ for $\mathrm{CBH}_{2 / 1}$ and $\mathrm{CBK}_{1 / 1}$ respectively.

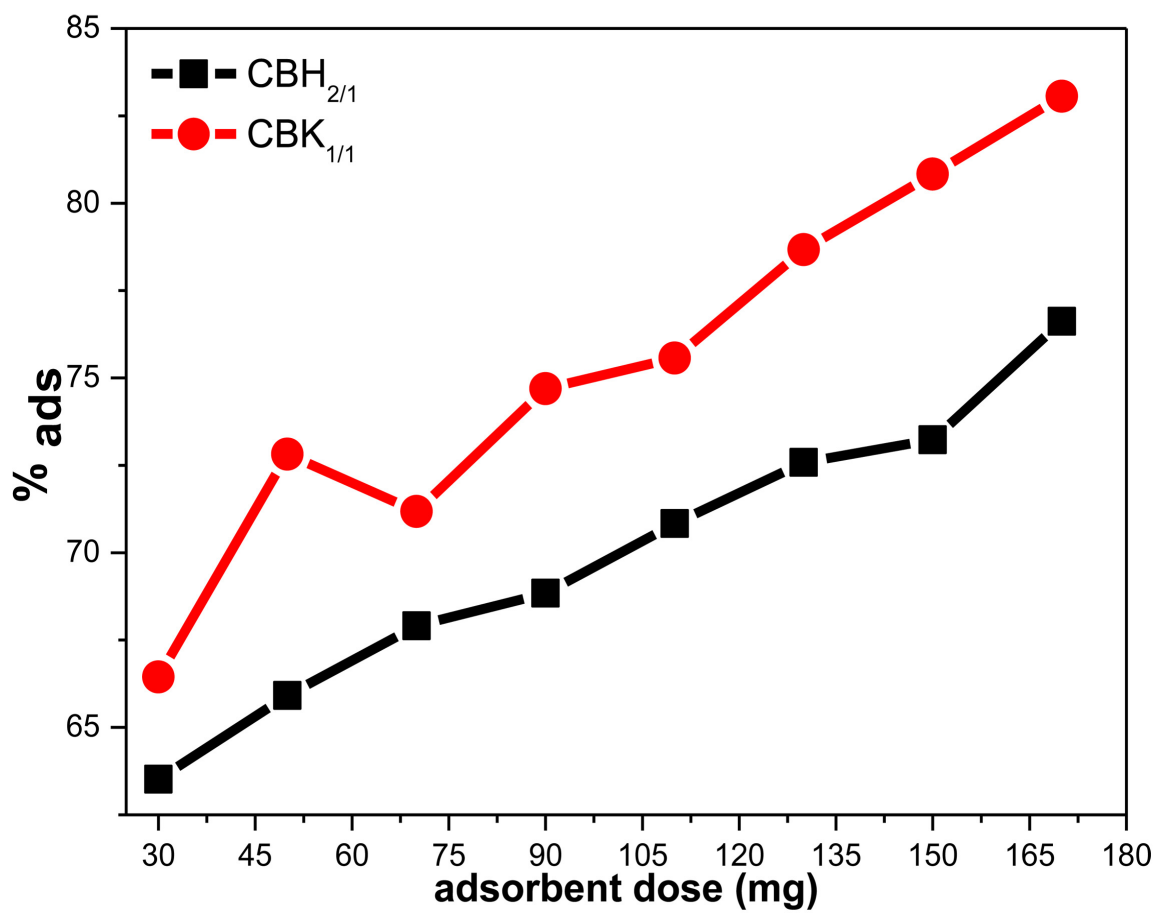

Figure 3. Effect of adsorbent dosage on the adsorption of thymol blue. 


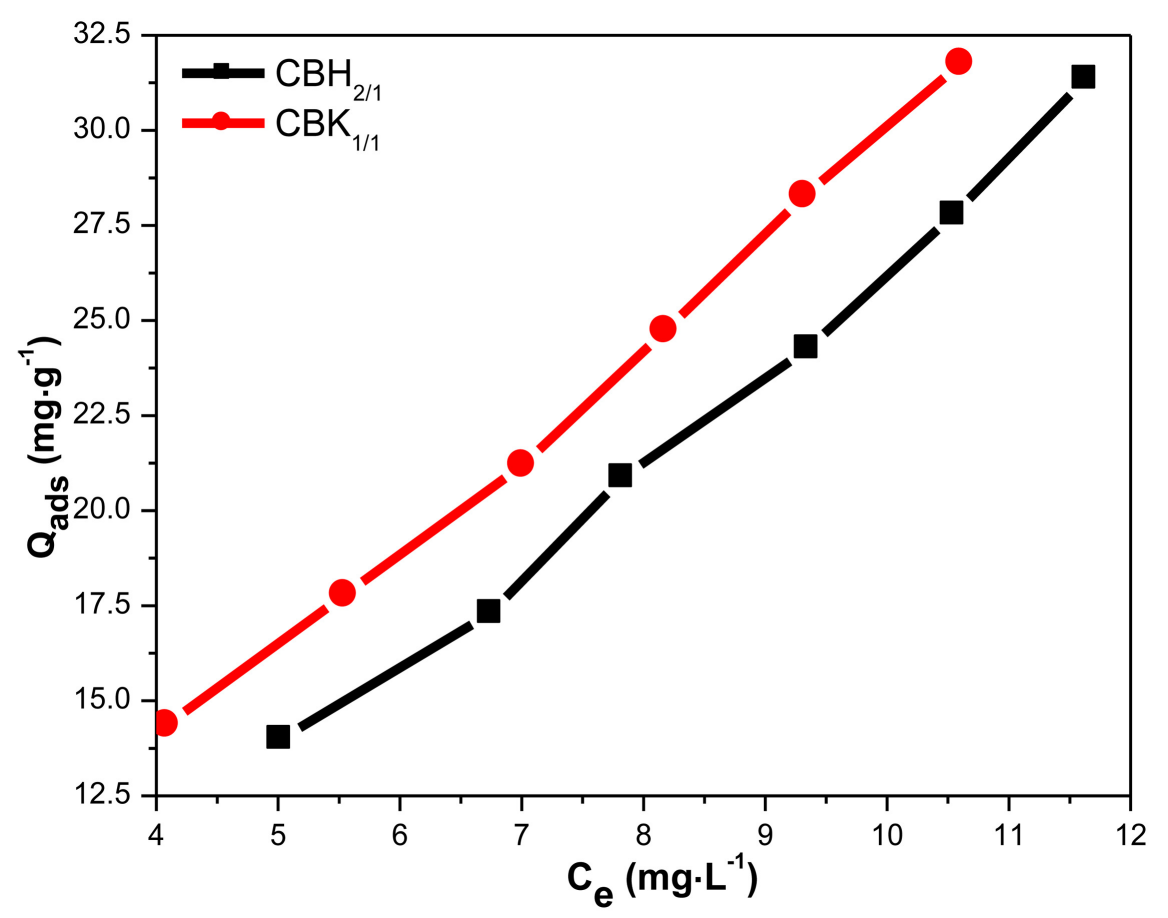

Figure 4. Effect of initial concentration on the adsorption of thymol blue.

The increasing adsorption capacities of the ACs with increase in concentration of thymol blue can be due to $\pi-\pi$ interactions between the organic compounds and functional groups of the carbon surface. The $\pi-\pi$ interactions in most cases are responsible for the mechanism of adsorption of aromatic compounds [14]. This result can also be explained by saying that, increasing the initial concentration of thymol blue leads to an increase in the driving force for mass transfer, and hence an increase in the rate at which thymol blue molecules pass from solution to the particle surface [38]. The quantity of thymol blue adsorption onto all samples of ACs did not show a plateau, suggesting that there was no monolayer formation on the surfaces of the adsorbents. The increase in adsorption capacity with increase in initial concentration indicates that, the ACs have a high potential for the removal of thymol blue from its solutions.

\subsubsection{Effect of Ionic Strength}

The ionic strength can be viewed as one of the factors that controls nonelectrostatic and electrostatic interactions between adsorbate and the surface of the adsorbent. The effect of ionic strength is also important in the study of adsorption of dye onto adsorbents. Ionic strength effect on the adsorption of thymol blue was investigated and the results are shown in Figure 5. In this figure, the adsorption capacities of dye at equilibrium decreased from 13.347 to $12.072 \mathrm{mg} \cdot \mathrm{g}^{-1}$ for $\mathrm{CBH}_{2 / 1}$ and 13.336 to $12.271 \mathrm{mg} \cdot \mathrm{g}^{-1}$ for $\mathrm{CBK}_{1 / 1}$ when the ionic strength increased from 0.01 to $0.06 \mathrm{~mol} \cdot \mathrm{L}^{-1}$. These results can be explained by the fact that, the surface of ACs becomes less accessible to thymol blue molecules when the quantity of $\mathrm{NaCl}$ salt in solution increases. For this reason, the amount of thymol blue adsorbed decreases. This result is in agreement with the literature, 


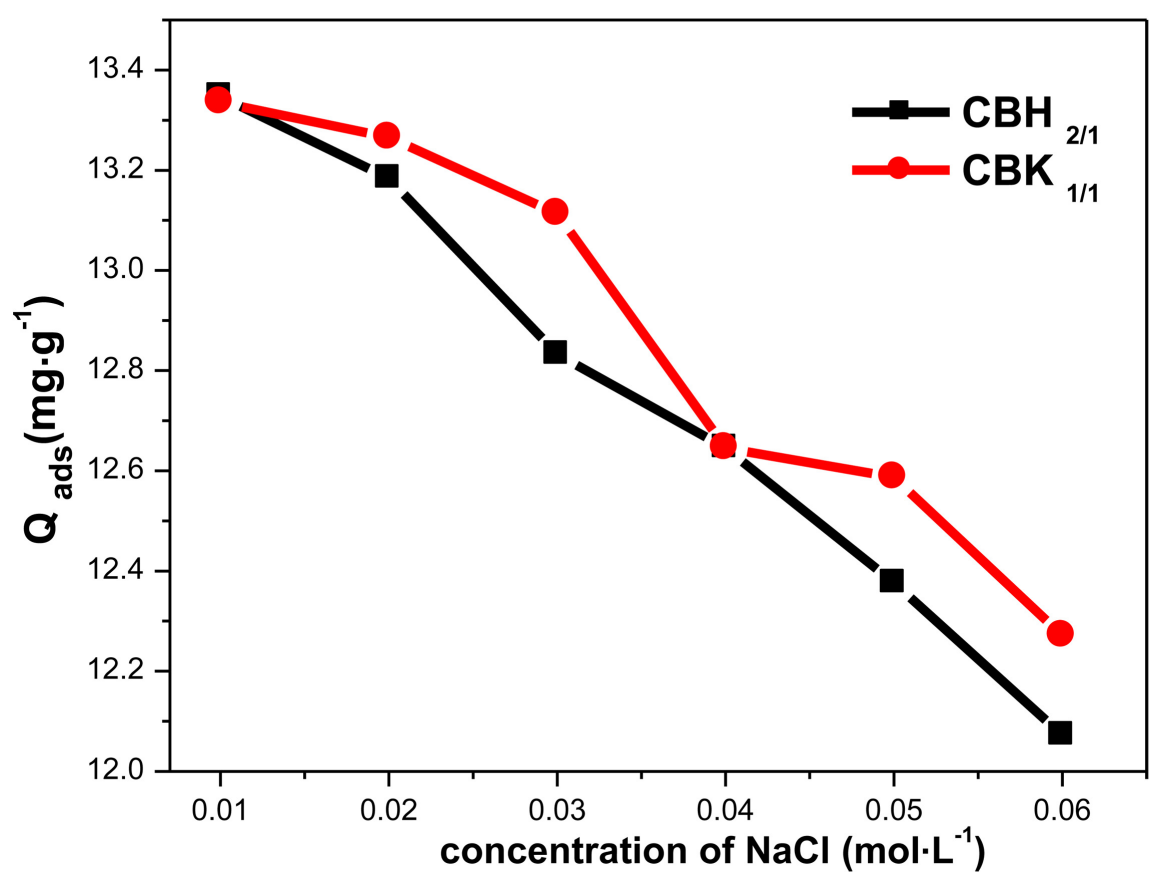

Figure 5. Effect of ionic strength on the adsorption of thymol blue.

which reports that when the electrostatic attraction forces between the adsorbent surface and adsorbate ions are attractive, an increase in ionic strength will decrease the adsorption capacity [40].

\subsection{Batch Kinetic Studies}

Pseudo-first order, pseudo-second order, intraparticle diffusion, Elovich, fractional power, Avrami and Tobin kinetics models are used to investigate and describe the mechanism of the adsorption process (see equation in Table 1). These kinetic models have been presented in different non-linear forms and Table 5 presents the calculated parameters.

According to Table 5, the non-linear models of pseudo-second order, Avrami and Tobin seem to be the most appropriate in adequately describing the adsorption phenomenon for the two ACs, $\mathrm{CBH}_{2 / 1}$ and $\mathrm{CBK}_{1 / 1}$ studied. As shown in Table 6, the coefficient of determination, $R^{2}$ of these models are very good $\left(R^{2}>\right.$ 0.95). However, the relatively higher $R^{2}$ values and the lower $\chi^{2}$, ERRSQ values and other relatively lower error functions for the Avrami model compared to the pseudo-second order and Tobinmodels confirm that the Avrami non-linear kinetic expression is best suited to describe the adsorption kinetics of thymol blue on the two ACs. The Avrami exponent $\left(n_{A V}\right)$ is a fractional number that is related to the possible changes in the adsorption mechanism that takes place during the adsorption process [41]. Therefore, instead of following only an integer-kinetic order, the adsorption mechanism could follow multiple kinetic orders. That is, during adsorption, the order of reaction can change from one value to another [41]. In this study, $\mathrm{n}_{\mathrm{AV}}$ exponent showed that the adsorption process was of the multiple kinetic order. The low values of $\chi^{2}$ and other error functions 
Table 5. Kinetic data obtained by non-linear fitting analysis (see equations in Table 1 and Table 3).

\begin{tabular}{|c|c|c|c|c|c|c|c|c|c|c|}
\hline Models & Constants & Values & $R^{2}$ & $x^{2}$ & RMSE & ERRSQ & HYBRID & ARE & MPSD & EABS \\
\hline \multicolumn{11}{|c|}{$\mathrm{CBH}_{2 / 1}$} \\
\hline $\begin{array}{l}\text { Pseudo-First } \\
\text { Order }\end{array}$ & $\begin{array}{l}Q_{e}\left(\mathrm{mg} \cdot \mathrm{g}^{-1}\right) \\
K_{1}\left(\mathrm{~min}^{-1}\right)\end{array}$ & $\begin{array}{l}14.387 \\
0.170\end{array}$ & 0.922 & 0.276 & 0.608 & 2.956 & 3.311 & 3.786 & 5.534 & 4.548 \\
\hline $\begin{array}{l}\text { Pseudo-Second } \\
\text { Order }\end{array}$ & $\begin{array}{l}Q_{e}\left(\mathrm{mg} \cdot \mathrm{g}^{-1}\right) \\
K_{2}\left(\mathrm{~g} \cdot \mathrm{mg}^{-1} \cdot \mathrm{min}^{-1}\right) \\
h\left(\mathrm{mg} \cdot \mathrm{g}^{-1} \cdot \mathrm{min}^{-1}\right)\end{array}$ & $\begin{array}{c}15.464 \\
0.0191 \\
4.567\end{array}$ & 0.963 & 0.087 & 0.378 & 1.141 & 1.097 & 2.273 & 2.933 & 2.999 \\
\hline $\begin{array}{l}\text { Intra-Particle } \\
\text { Diffusion }\end{array}$ & $\begin{array}{l}C\left(\mathrm{mg} \cdot \mathrm{g}^{-1}\right) \\
K_{i d} \\
\left(\mathrm{mg} \cdot \mathrm{g}^{-1} \cdot \mathrm{min}^{-0.5}\right)\end{array}$ & $\begin{array}{l}9.834 \\
0.593\end{array}$ & 0.681 & 0.781 & 1.113 & 9.909 & 10.461 & 7.209 & 9.6 & 9.016 \\
\hline Elovich & $\begin{array}{l}\alpha\left(\mathrm{mg} \cdot \mathrm{g}^{-1} \cdot \mathrm{min}^{-1}\right) \\
\beta\left(\mathrm{g} \cdot \mathrm{mg}^{-1}\right)\end{array}$ & $\begin{array}{l}113.57 \\
0.564\end{array}$ & 0.851 & 0.359 & 0.761 & 4.635 & 4.565 & 4.808 & 6.101 & 6.155 \\
\hline $\begin{array}{l}\text { Fractional } \\
\text { Power }\end{array}$ & $\begin{array}{l}K \\
V\end{array}$ & $\begin{array}{l}8.576 \\
0.130\end{array}$ & 0.803 & 0.464 & 0.858 & 5.885 & 6.018 & 5.52 & 7.156 & 6.971 \\
\hline Avrami & $\begin{array}{l}Q_{e}\left(\mathrm{mg}^{-g^{-1}}\right) \\
K_{A V}\left(\min ^{-1}\right) \\
n_{A V}\end{array}$ & $\begin{array}{l}14.771 \\
0.187 \\
0.642\end{array}$ & 0.974 & 0.063 & 0.318 & 0.811 & 0.802 & 2.035 & 2.548 & 2.624 \\
\hline Tobin & $\begin{array}{l}Q_{e}\left(\mathrm{mg} \cdot \mathrm{g}^{-1}\right) \\
K_{T} \\
n_{T}\end{array}$ & $\begin{array}{l}15.255 \\
0.249 \\
1.103\end{array}$ & 0.965 & 0.085 & 0.369 & 1.091 & 1.085 & 2.282 & 2.972 & 2.939 \\
\hline \multicolumn{11}{|c|}{$\mathrm{CBK}_{1 / 1}$} \\
\hline $\begin{array}{l}\text { Pseudo-First } \\
\text { Order }\end{array}$ & $\begin{array}{l}Q_{e}\left(\mathrm{mg} \cdot \mathrm{g}^{-1}\right) \\
K_{1}\left(\mathrm{~min}^{-1}\right)\end{array}$ & $\begin{array}{l}22.838 \\
0.068\end{array}$ & 0.755 & 0.301 & 0.701 & 3.927 & 3.935 & 4.184 & 5.708 & 5.518 \\
\hline $\begin{array}{l}\text { Pseudo-Second } \\
\text { Order }\end{array}$ & $\begin{array}{l}Q_{e}\left(\mathrm{mg} \cdot \mathrm{g}^{-1}\right) \\
K_{2}\left(\mathrm{~g} \cdot \mathrm{mg}^{-1} \cdot \mathrm{min}^{-1}\right) \\
h\left(\mathrm{mg} \cdot \mathrm{g}^{-1} \cdot \mathrm{min}^{-1}\right)\end{array}$ & $\begin{array}{c}16.075 \\
\\
0.02 \\
5.168\end{array}$ & 0.951 & 0.107 & 0.426 & 1.451 & 1.342 & 2.494 & 3.184 & 3.396 \\
\hline $\begin{array}{l}\text { Intra-Particle } \\
\text { Diffusion }\end{array}$ & $\begin{array}{l}C\left(\mathrm{mg} \cdot \mathrm{g}^{-1}\right) \\
K_{i d} \\
\left(\mathrm{mg} \cdot \mathrm{g}^{-1} \cdot \mathrm{min}^{-0.5}\right)\end{array}$ & $\begin{array}{l}10.591 \\
0.585\end{array}$ & 0.702 & 0.641 & 1.045 & 8.742 & 8.376 & 6.246 & 8.141 & 8.414 \\
\hline Elovich & $\begin{array}{l}\alpha\left(\mathrm{mg} \cdot \mathrm{g}^{-1} \cdot \mathrm{min}^{-1}\right) \\
\beta\left(\mathrm{g} \cdot \mathrm{mg}^{-1}\right)\end{array}$ & $\begin{array}{c}197.388 \\
0.576\end{array}$ & 0.862 & 0.288 & 0.711 & 4.039 & 3.621 & 4.056 & 5.152 & 5.605 \\
\hline $\begin{array}{l}\text { Fractional } \\
\text { Power }\end{array}$ & $\begin{array}{l}K \\
V\end{array}$ & $\begin{array}{l}9.296 \\
0.121\end{array}$ & 0.822 & 0.367 & 0.794 & 5.042 & 4.659 & 4.656 & 5.950 & 6.352 \\
\hline Avrami & $\begin{array}{l}Q_{e}\left(\mathrm{mg} \mathrm{g}^{-1}\right) \\
K_{A V}\left(\min ^{-1}\right) \\
n_{A V}\end{array}$ & $\begin{array}{l}15.576 \\
0.213 \\
0.562\end{array}$ & 0.961 & 0.084 & 0.379 & 1.146 & 1.044 & 2.129 & 2.785 & 2.909 \\
\hline Tobin & $\begin{array}{l}Q_{e}\left(\mathrm{mg} \mathrm{g}^{-1}\right) \\
K_{T} \\
n_{T}\end{array}$ & $\begin{array}{l}16.188 \\
0.354 \\
0.952\end{array}$ & 0.951 & 0.105 & 0.424 & 1.440 & 1.311 & 2.441 & 3.123 & 3.355 \\
\hline
\end{tabular}


I.-H. T. Kuete et al.

Table 6. Adsorption of thymol blue: non-linear fitting analysis for two-parameter isotherms (see Equations in Table 2 and Table 3).

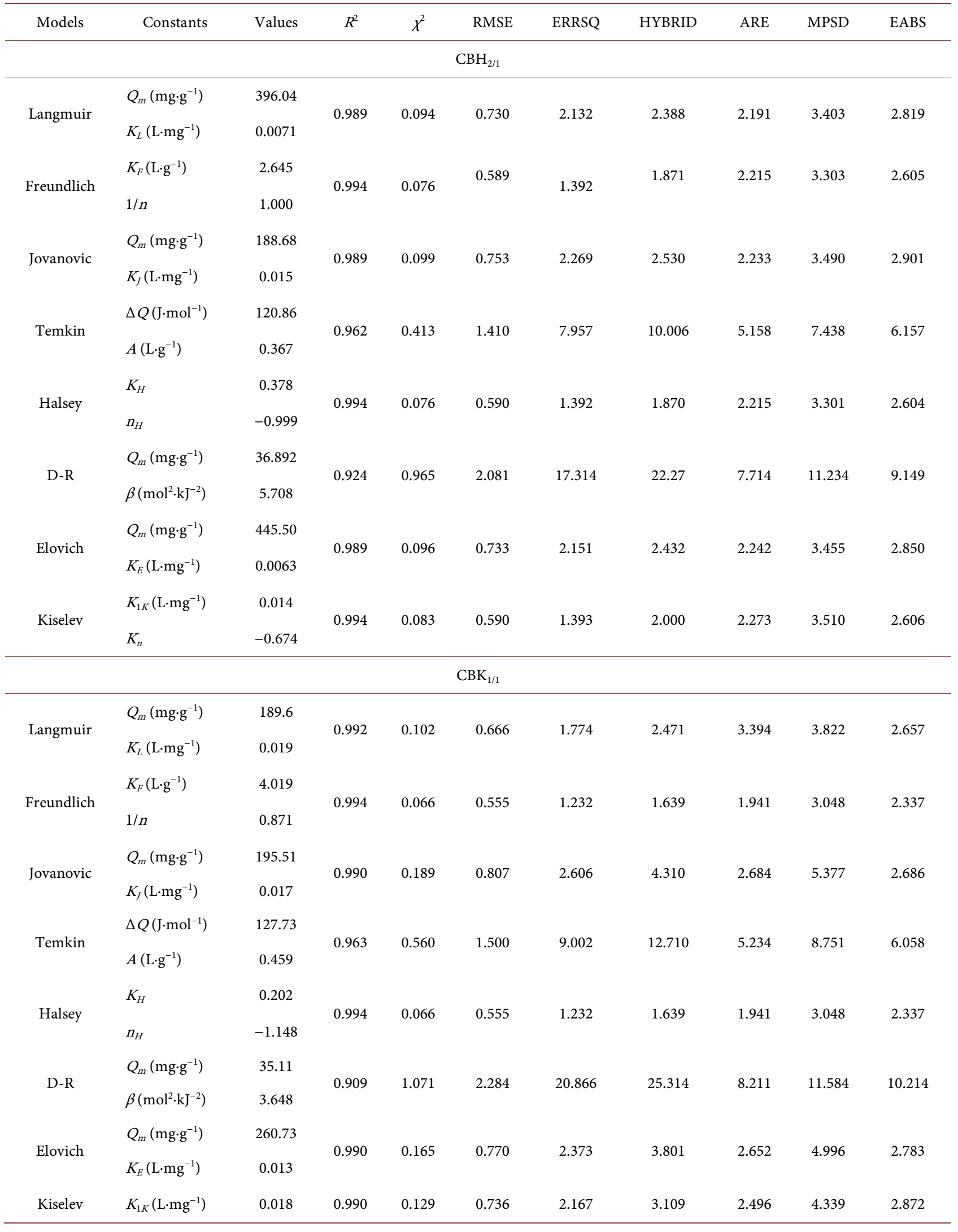


of the Tobin and pseudo-second order models suggest that these two models equally describe the kinetics of thymol blue uptake onto the ACs. The values of $V$ lower than unity obtained for the fractional power kinetic model suggest that fractional power may also describe the adsorption kinetics of the thymol blue-AC system. Adsorption data obtained from the pseudo-second order kinetic model thus indicate that the adsorption of thymol blue onto the ACs $\mathrm{CBH}_{2 / 1}$ and $\mathrm{CBK}_{1 / 1}$ may also be of a chemical nature.

\subsection{Adsorption Isotherms}

Adsorption isotherms describe the relationship between the quantity of adsorbate adsorbed by the adsorbent $\left(Q_{e}\right)$ and the concentration of adsorbate remaining at equilibrium $\left(C_{e}\right)$. This part aims at finding the models that can accurately describe the data obtained from the experiments of the adsorption thymol blue onto $\mathrm{CBH}_{2 / 1}$ and $\mathrm{CBK}_{1 / 1}$, and then to specify the parameters that can be determined. Eight models of two-parameter isotherms, seven models of three-parameter isotherms, two models of four-parameter isotherms and one model of five-parameter isotherms were studied (see equation in Table 2).

\subsubsection{Two Parameter Models}

The capabilities of the equations of the two-parameter isotherms to model equilibrium adsorption data were examined and Table 6 also presents the calculated parameters of the adsorption isotherms and their characterizations obtained using the non-linear model analysis.

It can be observed from the table that for the two ACs, the coefficient of determination for all the models is very good $\left(R^{2}>0.96\right)$ except for the DubininRadushkevich model. Thus, in this table the lower values of chi-square $\left(\chi^{2}\right)$, RMSE, ERRSQ, ARE and other error functions for each isotherm model will determine the best model. Among the two-parameter equations tested, and based on the low values of the error functions and the high determination coefficient, the best representation of the experimental data of the adsorption of thymol blue is obtained using the isotherms of Freundlich, Halsey and Kiselev for $\mathrm{CBH}_{2 / 1}$; and those of Freundlich, Halsey and Langmuir for $\mathrm{CBK}_{1 / 1}$. In this table, the Halsey adsorption isotherm confirms the multilayer adsorption and the heteroporous nature of the adsorbents. The values of $1 / \mathrm{n}$ for the Freundlich model are equal and lower than 1 ( 1.000 for $\mathrm{CBH}_{2 / 1}$ and 0.871 for $\left.\mathrm{CBK}_{1 / 1}\right)$, thereby indicating the high affinity between these ACs and thymol blue solution. This also indicates that adsorption took place through a physical process, and that there was a greater heterogeneity of the adsorption sites on the adsorbent. The $1 / n=1$ for $\mathrm{CBH}_{2 / 1}$ indicates that the isotherm is linear, and is of the type $\mathrm{C}$, while for $\mathrm{CBK}_{1 / 1}$, the value of $1 / n<1$ indicates the isotherm to be concave, and hence of type L.

For $\mathrm{CBH}_{2 / 1}$ the negative value of $k_{n}$ for the Kiselev isotherm shows that there is no complex formed between the adsorbed thymol blue molecules and the AC. On the other hand, the positive value of $k_{n}$ with $\mathrm{CBK}_{1 / 1}$ shows the formation of a 
complex between the adsorbed thymol blue molecules and the AC. The Jovanovic isotherm describes an approximation of a monolayer localized adsorption without lateral interactions. The results of the Temkin model show that the change in the adsorption energy for the two ACs is higher than zero, thus indicating that the process of adsorption is exothermic.

For the Langmuir isotherm, the values of the separation factor falling between 0 - 1 (Figure 6) show a favorable adsorption of thymol blue by the two ACs. This result is in agreement with what was already observed with the Freundlich isotherm.

\subsubsection{Three Parameter Models}

The capabilities of the equations of the three-parameter isotherms to model equilibrium adsorption data were examined. Table 7 presents the calculated parameters of the adsorption isotherms and their characterizations obtained using the non-linear model analysis.

It can be observed in Table 8 that for the two ACs, the coefficient of determination for all models is very good $\left(R^{2}>\right.$ the 0.96$)$. Thus, in this table, the lower values of the chi-square $\left(\chi^{2}\right)$, RMSE, ERRSQ, ARE and other error functions for each isotherm model and high value of determination coefficient will determine the best model. According to these values, the best-fitted adsorption isotherm models were found in the order: Fritz-Schlunder III > Redlich-peterson > Radke-Prausnitz $>$ Jossens $>$ Toth $>$ Langmuir-Freundlich $>$ Hill for $\mathrm{CBH}_{2 / 1}$ predicting the adsorption to be on heterogeneous surfaces; Fritz-Schlunder III $>$ Redlich-peterson $>$ Radke-Prausnitz $>$ Hill $>$ Langmuir-Freundlich $>$ Jossens $>$ Toth for $\mathrm{CBK}_{1 / 1}$ predicting the adsorption process as a cooperative phenomenon

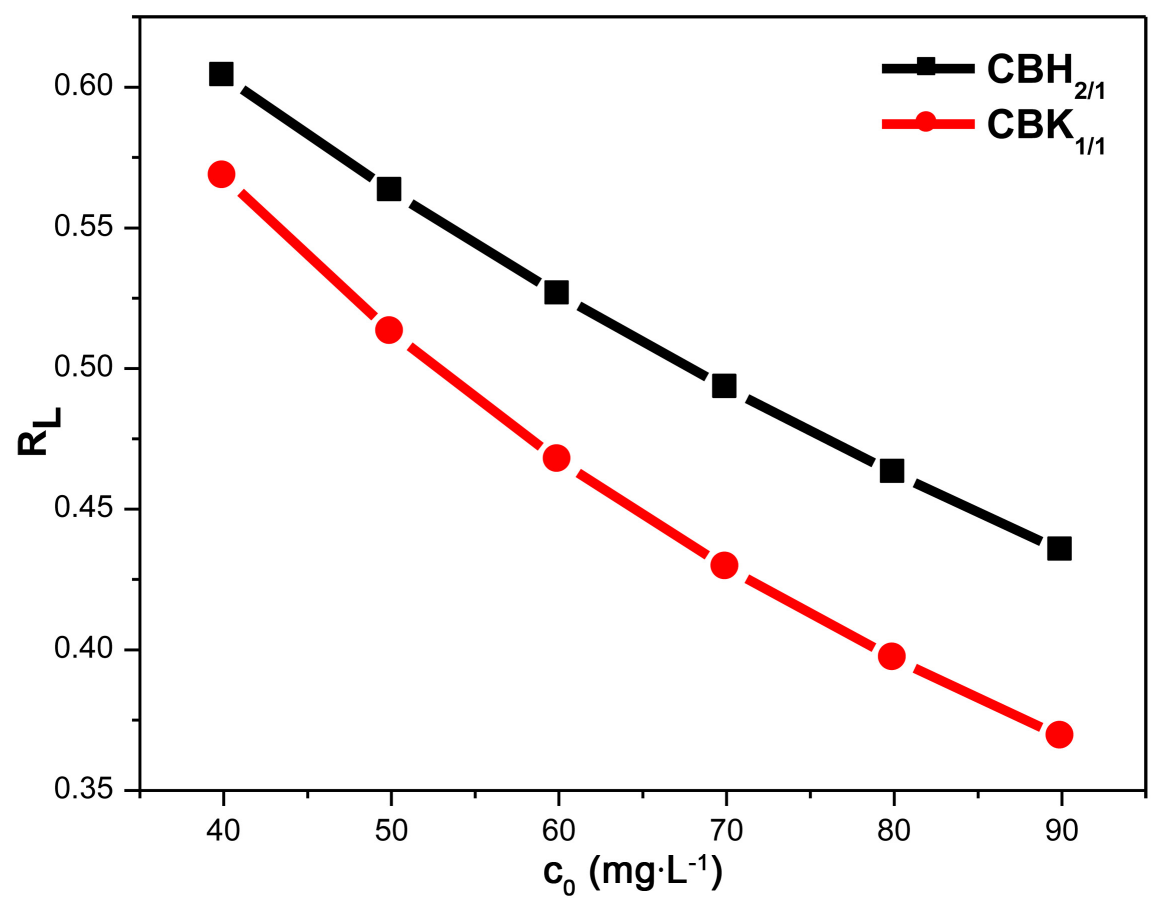

Figure 6. Evolution of separation factor against the initial concentration of thymol blue. 
I.-H. T. Kuete et al.

Table 7. Adsorption of thymol blue: Non-linear fitting analysis for three-parameter isotherms (see Equations in Table 2 and Table 3).

\begin{tabular}{|c|c|c|c|c|c|c|c|c|c|c|}
\hline Models & Constants & Values & $R^{2}$ & $x^{2}$ & RMSE & ERRSQ & HYBRID & ARE & MPSD & EABS \\
\hline \multicolumn{11}{|c|}{$\mathrm{CBH}_{2 / 1}$} \\
\hline & $K_{R P}\left(\mathrm{~L} \cdot \mathrm{g}^{-1}\right)$ & 2.898 & & & & & & & & \\
\hline \multirow[t]{3}{*}{ Redlich-Peterson } & $A_{R P}\left(\mathrm{~L} \cdot \mathrm{mg}^{-1}\right)$ & 0.091 & 0.993 & 0.075 & 0.590 & 1.393 & 2.478 & 2.206 & 3.788 & 2.599 \\
\hline & $g$ & 0.0099 & & & & & & & & \\
\hline & $Q_{S H}\left(\mathrm{mg} \cdot \mathrm{g}^{-1}\right)$ & 198.96 & & & & & & & & \\
\hline \multirow[t]{3}{*}{ Hill } & $K_{D}$ & 61.164 & 0.990 & 0.115 & 0.737 & 2.170 & 3.746 & 2.547 & 4.628 & 3.018 \\
\hline & $n_{H}$ & 1.198 & & & & & & & & \\
\hline & $Q_{m R P}\left(\mathrm{mg} \cdot \mathrm{g}^{-1}\right)$ & 60.903 & & & & & & & & \\
\hline \multirow[t]{2}{*}{ Radke-Prausnitz } & $K_{R P}\left(\mathrm{~L} \cdot \mathrm{mg}^{-1}\right)$ & 0.043 & 0.994 & 0.076 & 0.590 & 1.393 & 2.484 & 2.209 & 3.797 & 2.602 \\
\hline & $m_{R P}$ & 0.001 & & & & & & & & \\
\hline \multirow[t]{3}{*}{ Langmuir-Freundlich } & $m_{L F}$ & 1.144 & 0.991 & 0.104 & 0.692 & 1.916 & 3.383 & 2.470 & 4.437 & 2.908 \\
\hline & $K_{L F}$ & 0.022 & & & & & & & & \\
\hline & $Q_{m T}\left(\mathrm{mg} \cdot \mathrm{g}^{-1}\right)$ & 81.080 & & & & & & & & \\
\hline \multirow[t]{3}{*}{ Toth } & $n$ & 2.721 & 0.991 & 0.087 & 0.686 & 1.885 & 2.898 & 2.196 & 3.852 & 2.719 \\
\hline & $K_{T}$ & 0.033 & & & & & & & & \\
\hline & $H$ & 2.670 & & & & & & & & \\
\hline \multirow[t]{3}{*}{ Jossens } & $F$ & 0.0063 & 0.994 & 0.0755 & 0.590 & 1.394 & 2.484 & 2.209 & 3.796 & 2.602 \\
\hline & $p$ & 0.0508 & & & & & & & & \\
\hline & $Q_{m F S}\left(\mathrm{mg} \cdot \mathrm{g}^{-1}\right)$ & 32.147 & & & & & & & & \\
\hline \multirow[t]{2}{*}{ Fritz-Schlunder } & $K_{F S}\left(\mathrm{~L} \cdot \mathrm{mg}^{-1}\right)$ & 2.739 & 0.994 & 0.075 & 0.590 & 1.392 & 2.477 & 2.205 & 3.786 & 2.599 \\
\hline & $m_{F S}$ & 0.0009 & & & & & & & & \\
\hline \multirow{4}{*}{ Redlich-Peterson } & $K_{R P}\left(\mathrm{~L} \cdot \mathrm{g}^{-1}\right)$ & 10.688 & & & & & & & & \\
\hline & $A_{R P}\left(\mathrm{~L} \cdot \mathrm{mg}^{-1}\right)$ & 1.698 & 0.9942 & 0.068 & 0.562 & 1.264 & 2.253 & 1.963 & 2.531 & 2.359 \\
\hline & $g$ & 0.181 & & & & & & & & \\
\hline & $Q_{S H}\left(\mathrm{mg} \cdot \mathrm{g}^{-1}\right)$ & 196.92 & & & & & & & & \\
\hline \multirow[t]{3}{*}{ Hill } & $K_{D}$ & 54.67 & 0.992 & 0.097 & 0.6597 & 1.741 & 3.151 & 2.264 & 4.285 & 2.720 \\
\hline & $n_{H}$ & 0.988 & & & & & & & & \\
\hline & $Q_{m R P}\left(\mathrm{mg} \cdot \mathrm{g}^{-1}\right)$ & 68.317 & & & & & & & & \\
\hline \multirow[t]{3}{*}{ Radke-Prausnitz } & $K_{R P}\left(\mathrm{~L} \cdot \mathrm{mg}^{-1}\right)$ & 0.052 & 0.992 & 0.096 & 0.648 & 1.681 & 3.115 & 2.213 & 4.287 & 2.602 \\
\hline & $m_{R P}$ & 0.438 & & & & & & & & \\
\hline & $Q_{m L F}\left(\mathrm{mg} \cdot \mathrm{g}^{-1}\right)$ & 174.40 & & & & & & & & \\
\hline \multirow[t]{3}{*}{ Langmuir-Freundlich } & $m_{L F}$ & 1.002 & 0.992 & 0.098 & 0.671 & 1.802 & 3.200 & 2.338 & 4.264 & 2.803 \\
\hline & $K_{L F}$ & 0.0206 & & & & & & & & \\
\hline & $Q_{m T}\left(\mathrm{mg} \cdot \mathrm{g}^{-1}\right)$ & 85.551 & & & & & & & & \\
\hline \multirow[t]{3}{*}{ Toth } & $n$ & 1.677 & 0.991 & 0.128 & 0.730 & 2.130 & 4.083 & 2.467 & 4.983 & 2.838 \\
\hline & $K_{T}$ & 0.039 & & & & & & & & \\
\hline & $H$ & 3.955 & & & & & & & & \\
\hline \multirow[t]{3}{*}{ Jossens } & $F$ & 0.044 & 0.992 & 0.111 & 0.686 & 1.883 & 3.570 & 2.309 & 4.629 & 2.677 \\
\hline & $p$ & 0.543 & & & & & & & & \\
\hline & $Q_{m F S}\left(\mathrm{mg} \cdot \mathrm{g}^{-1}\right)$ & 67.494 & & & & & & & & \\
\hline \multirow[t]{2}{*}{ Fritz-Schlunder } & $K_{F S}\left(\mathrm{~L} \cdot \mathrm{mg}^{-1}\right)$ & 4.077 & 0.994 & 0.066 & 0.555 & 1.233 & 2.188 & 1.941 & 3.522 & 2.337 \\
\hline & $m_{F S}$ & 0.131 & & & & & & & & \\
\hline
\end{tabular}


I.-H. T. Kuete et al.

Table 8. Adsorption of thymol blue: Non-linear fitting analysis of four- and five-parameter isotherms (see Equations in Table 2 and Table 3).

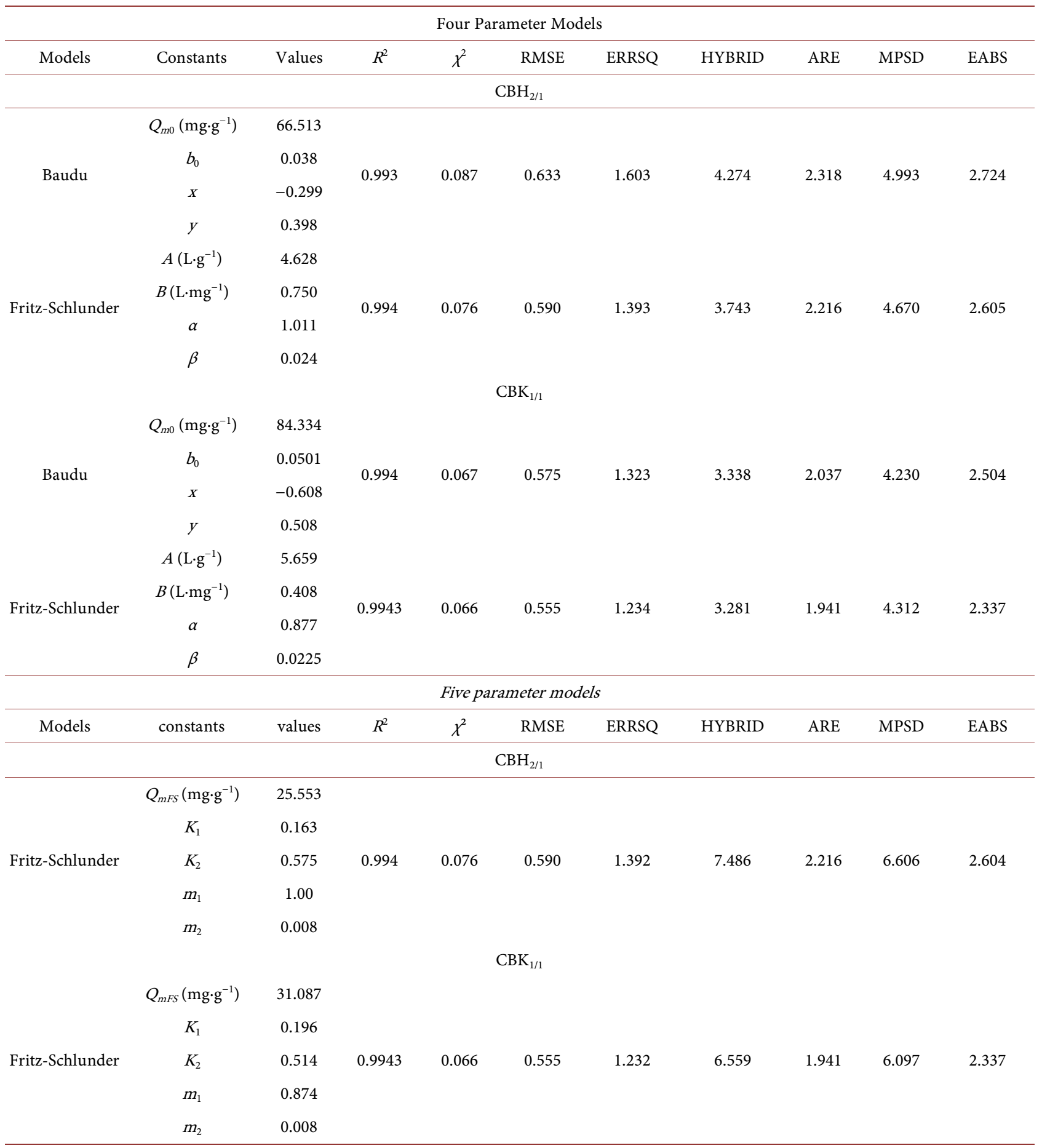

with adsorbates at one site of the adsorbent influencing different binding sites on the same adsorbent on heterogeneous surfaces. The maximum adsorption capacity obtained using the Fritz-Schlunder III equation is $32.147 \mathrm{mg} \cdot \mathrm{g}^{-1}$ for $\mathrm{CBH}_{2 / 1}$ and $67.494 \mathrm{mg} \cdot \mathrm{g}^{-1}$ for $\mathrm{CBK}_{1 / 1}$. The values of $g$ and $m_{F S}$ obtained using Redlich-Peterson and Fritz-Schlunder III isotherms are lower than 1, which 
means that the adsorption of thymol blue by the ACs cannot be reduced to the Langmuir isotherm. This implies that the adsorption already predicted to be on heterogeneous surfaces is also confirmed by the Jossens model. For the two ACs, it was observed that $\mathrm{n}$ was greater than unity. This suggests that the interactions between the adsorbed molecules are stronger than the adsorptive potential.

\subsubsection{Four and Five Parameter Models}

Isotherms of four-parameters (Fritz-Schlunder IV and Baudu) and five-parameters (Fritz-Schlunder V) were used to model the equilibrium data of adsorption of thymol blue and Table 8 presents the calculated parameters of the adsorption isotherms and their characterizations obtained using non-linear model analysis.

It can be observed from Table 8 that the coefficients of determination for all models are very good $\left(R^{2}>0.99\right)$. Based on the low values of ERRSQ and other error functions, high coefficients of determination, the two four-parameter isotherms gave a good fitting of the experimental results for both $\mathrm{CBH}_{2 / 1}$ and $\mathrm{CBK}_{1 / 1}$. The maximum adsorption capacity obtained using the Baudu isotherm were higher than those calculated by the Fritz-Schlunder-III model. However, according to Fritz-Schlunder-III and Baudu isotherm models, $\mathrm{CBK}_{1 / 1}$ gave a higher maximum adsorption capacity than $\mathrm{CBH}_{2 / 1}$. Examining the exponent values in the Fritz-Schlunder-IV model, $\alpha$ approached unity while $\beta$ did not, indicating that the adsorption data could not preferably be fitted with the Langmuir isotherm.

The adsorption data were analyzed according to the non-linear form of the five-parameter isotherm model of Fritz-Schlunder- $\mathrm{V}$ and a satisfactory fitting of the experimental result was obtained, using the high values of the coefficient of determination and the lower values of error functions according to table 8 below. From the results obtained we can say that this model also describes the adsorption of thymol blue on $\mathrm{CBK}_{1 / 1}$ and $\mathrm{CBH}_{2 / 1}$. The model exponents of the Fritz-Schlunder-V isotherm, $m_{1}\left(1.00\right.$ for $\mathrm{CBH}_{2 / 1} ; 0.874$ for $\left.\mathrm{CBK}_{1 / 1}\right)$ close to unity and $\mathrm{m}_{2}\left(0.008\right.$ for $\mathrm{CBH}_{2 / 1}$ and $\left.\mathrm{CBK}_{1 / 1}\right)$ very far away from unity, show that the adsorption data did not follow the hypotheses of the Langmuir isotherm.

Comparing the selected isotherm models used, we can say from the values of the determination coefficient and the values of error functions, that the models with 3, 4 and 5 parameters better described the adsorption process than the models with 2 parameters for the two ACs.

\subsection{Effect of Temperature and Thermodynamic Study}

The results of the effect of temperature on the adsorption of thymol blue are shown in Figure 7 below. The adsorption of thymol blue appears to be significantly affected by the temperature which influences the quantity adsorbed. We found that as the temperature increased from $35^{\circ} \mathrm{C}$ to $65^{\circ} \mathrm{C}$, the adsorption capacity also increased from $15.08 \mathrm{mg} \cdot \mathrm{g}^{-1}$ to $18.062 \mathrm{mg} \cdot \mathrm{g}^{-1}$ for $\mathrm{CBH}_{2 / 1}$ and 15.711 $\mathrm{mg} \cdot \mathrm{g}^{-1}$ to $18.659 \mathrm{mg} \cdot \mathrm{g}^{-1}$ for $\mathrm{CBK}_{\mathrm{l} / 1}$. Hence, a change in temperature has an impact on the adsorption efficiency and the adsorption capacity of the adsorbent. 


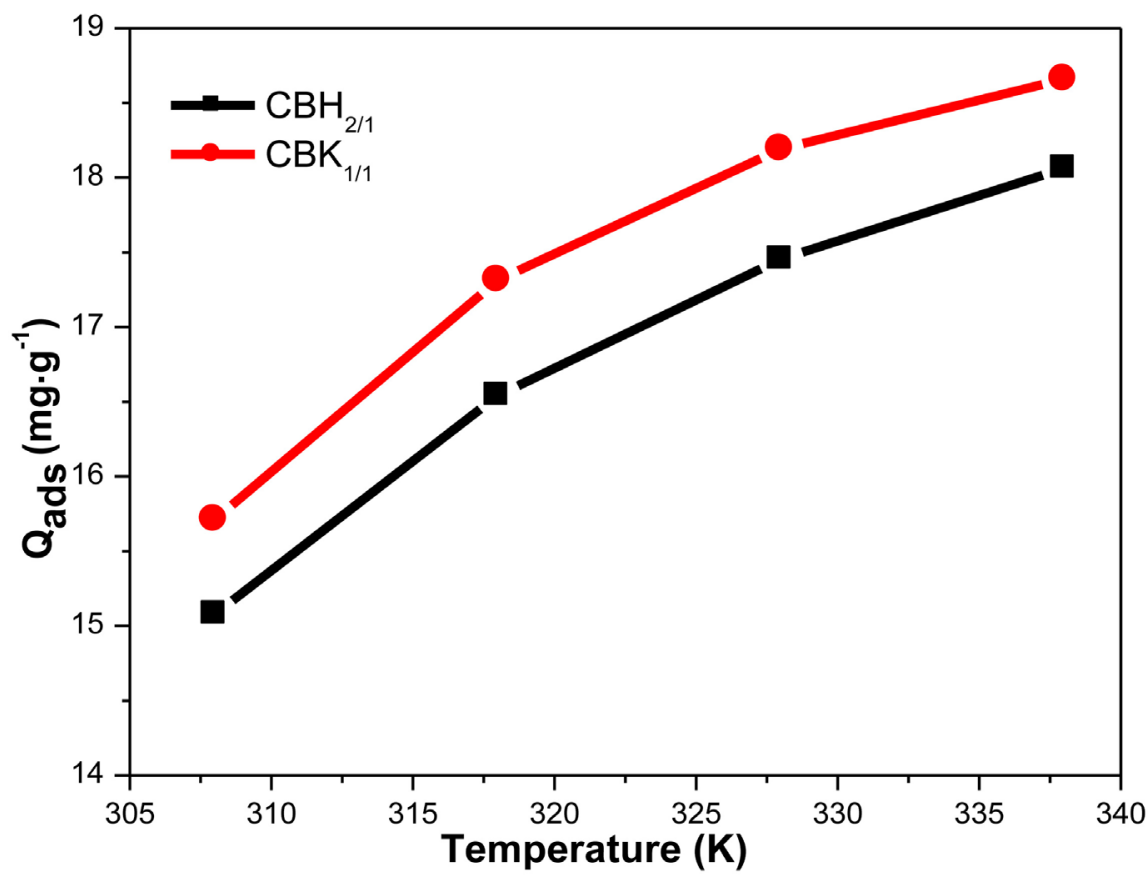

Figure 7. Effect of temperature.

Higher temperatures could also lead to stronger interactions during the formation of intermolecular hydrogen bonding between thymol blue and the two ACs, which is an important contribution to the adsorption process. Also, the rise in solution temperature increased the surface activity and kinetic energy of the thymol blue molecules which in turn increased mass transfer across the liquid film surrounding the different particles of the activated carbons.

The thermodynamic behavior for the adsorption on the two ACs was studied in more detail. The thermodynamic parameters such as the changes in Gibbs free energy $\left(\Delta G^{\circ}\right)$, enthalpy $\left(\Delta H^{\circ}\right)$, and entropy $\left(\Delta S^{\circ}\right)$ were calculated using the following equations:

$$
\begin{aligned}
& \Delta G^{\circ}=\Delta H^{\circ}-T \Delta S^{\circ} \\
& \ln K_{D}=\frac{-\Delta H^{\circ}}{R T}+\frac{\Delta S^{\circ}}{R}
\end{aligned}
$$

where,

$$
K_{D}=\frac{Q_{e}}{C_{e}}
$$

$K_{D}$ is the distribution coefficient for adsorption, $Q_{e}$ is the adsorption capacity at different temperature $\left(\mathrm{mg} \cdot \mathrm{g}^{-1}\right)$ and $C_{e}$ is the equilibrium dye concentration in solution $\left(\mathrm{mg} \cdot \mathrm{L}^{-1}\right), R$ is the gas constant $\left(8.314 \mathrm{~J} \cdot \mathrm{mol}^{-1} \cdot \mathrm{K}^{-1}\right)$, and $T$ is absolute temperature $(K)$. The Van't Hoff Equation (33) was plotted and the plot was used to calculate the change in enthalpy $\left(\Delta H^{\circ}\right)$ and entropy $\left(\Delta S^{\circ}\right)$ of adsorption for the adsorption of thymol blue. The results were used to determine the change in Gibbs free energy (32). These thermodynamic quantities are presented in Table 9 below. 
Table 9. Thermodynamic parameters for the adsorption of thymol blue onto the three ACs.

\begin{tabular}{|c|c|c|c|c|c|c|}
\hline \multicolumn{5}{|c|}{$\Delta G^{\mathrm{o}}\left(\mathrm{kJ} \cdot \mathrm{mol}^{-1}\right)$} & \multirow{2}{*}{$\begin{array}{c}\Delta H^{\circ} \\
\left(\mathrm{kJ} \cdot \mathrm{mol}^{-1}\right)\end{array}$} & \multirow{2}{*}{$\Delta S^{\mathrm{o}}\left(\mathrm{J} \cdot \mathrm{mol}^{-1} \cdot \mathrm{K}^{-1}\right)$} \\
\hline ACs & $308 \mathrm{~K}$ & $318 \mathrm{~K}$ & $328 \mathrm{~K}$ & $338 \mathrm{~K}$ & & \\
\hline $\mathrm{CBH}_{2 / 1}$ & -0.582 & -1.642 & -2.702 & -3.762 & 32.059 & 105.978 \\
\hline $\mathrm{CBK}_{1 / 1}$ & -1.092 & -2.381 & -3.671 & -4.96 & 38.612 & 128.91 \\
\hline
\end{tabular}

The negative values of $\Delta G^{\circ}$ for the temperature range $308 \mathrm{~K}$ to $338 \mathrm{~K}$ indicate that the adsorption of thymol blue onto the ACs is a spontaneous process. The decrease of $\Delta G^{\circ}$ values with the increase of temperature indicates that the adsorption became less favorable at higher temperatures [42]. The positive values of $\Delta H^{P}$ show that the adsorption process is endothermic. The change in entropy $\left(\Delta S^{\circ}\right)$ was positive, indicating that the entropy of the system increased during the adsorption process. However, it should also be noted that the entropy of the universe (including the system and the surroundings) might increase because the adsorption process was not an isolated one [9]. A positive value of $\Delta S^{\circ}$ reflects the affinity of the adsorbent towards the adsorbate species.

\section{Conclusions}

The ACs prepared from garcinia cola nut shell were characterized to obtain their physic-chemical properties. They were used to adsorb thymol blue from aqueous solution by batch process. Textural characteristics obtained by $\mathrm{N}_{2}$ adsorptiondesorption analysis showed that the surfaces of the ACs were heterogeneous, and contained micropores and mesopores.

Batch adsorption studies showed that increasing initial dye concentration enhanced the interaction between thymol blue and ACs which resulted in the increase of adsorption capacity. Electrostatic attraction and $\pi-\pi$ interactions were shown to dominate the adsorption mechanism. The quantity of thymol blue adsorbed increased with increasing temperature. According to seven different error functions and coefficient of determination, kinetic studies shows that, the adsorption data best fitted the Avrami non-linear equation and the pseudo-second order kinetic model thus indicating that the adsorption of thymol blue on the ACs may also be of a chemical nature. Isotherms models confirmed that the system is heterogeneous in nature and the adsorption is of a physical nature.

In future studies, we plan to use these activated carbons for the purification of biogas by adsorption of the $\mathrm{H}_{2} \mathrm{~S}$ contained in the synthesized mixture. We also intend to use the activated carbons in studies of column adsorption.

\section{Acknowledgements}

The authors are grateful for technical assistance rendered by Doungmo Giscard of the Institute of Inorganic Chemistry, Christian-Albrechts-Universität zu Kiel, Max-Eyth-Straße 2, 24118 Kiel, Germany, the World Academy of Sciences and the researchers of Materials and Process Engineering Team/RU-NOGEE of the 
Department of Chemistry, Faculty of Science of the University of Dschang, Cameroon.

\section{Conflicts of Interest}

Authors have declared a no competing interests regarding the publication of this paper.

\section{References}

[1] Ndifor-Angwafor, N.G., Kuete, T.I-H., Tchuifon, T.D.R., Ngakou, S.C., Bopda, A., Anagho, S.G. and Kamdem, T.A. (2017) Biosorption of Amaranth Red in Aqueous Solution onto Treated and Untreated Lignocellulosic Materials (Pineapple Peelings and Coconut Shells). Journal of Materials and Environmental Sciences, 8, 4199-4212. https://doi.org/10.26872/jmes.2017.8.12.441

[2] Wu, Y., He, J. and Yang, L. (2010) Evaluating Adsorption and Biodegradation Mechanisms during the Removal of Microcystin-RR by Periphyton. Environmental Science and Technology, 44, 6319-6324. https://doi.org/10.1021/es903761y

[3] Rangabhashiyam, S., Anu, N., Giri, M.S.N. and Selvaraju, N. (2014) Relevance of Isotherm Models in Biosorption of Pollutants by Agricultural Byproducts. Journal of Environmental Chemical Engineering, 2, 398-414. https://doi.org/10.1016/j.jece.2014.01.014

[4] Gao, J.F., Zhang, Q., Su, K. and Wang, J.H. (2010) Competitive Biosorption of Yellow $2 \mathrm{G}$ and Reactive Brilliant Red K-2G onto Inactive Aerobic Granules: Simultaneous Determination of Two Dyes by First Order Derivative Spectrophotometry and Isotherm Studies. Bioresource Technology, 101, 5793-5801.

https://doi.org/10.1016/j.biortech.2010.02.091

[5] Zaviska, F., Patrick, D., Guy, M. and Jean-François, B. (2009) Procédés d'oxydation avancée dans le traitement des eaux et des effluents industriels: Application à la dégradation des polluants. Journal of Water Science, 22, 535-564. https://doi.org/10.7202/038330ar

[6] Allen, S.J. and Koumanova, B. (2005) Decolourization of Water/Wastewater Using Adsorption. (Review). Journal of the University of Chemical Technology and Metallurgy, 40, 175-192.

[7] Chakrabarti, T., Subrahmanyan, O.V.E. and Sundaresan, B.B. (1988) Biodegradation of Recalcitrant Industrial Wastes. Biological treatment System, 2, 172-234.

[8] Grag, V.K., Kumar, R. and Gupta, R. (2004) Removal of Malachite Green Dye from Aqueous Solution by Adsorption Using Agro-Industries Waste: A Case Study of Phosppis Cineraria. Dyes and Pigments, 62, 1-10. https://doi.org/10.1016/j.dyepig.2003.10.016

[9] Aseel, M.A., Abbas, N.A. and Ayad, F.A. (2017) Kinetics and Equilibrium Study for the Adsorption of Textile Dyes on Coconut Shell Activated Carbon. Arabian Journal of Chemistry, 10, S3381-S3393. https://doi.org/10.1016/j.arabjc.2014.01.020

[10] Gupta, V.K., Mettal, A., Krishan, L. and Mittal, J. (2006) Adsorption Treatment and Recovery of the Hazardous Dye Brilliant Blue FCF, over Bottom Ash and De-Oiled Soya. Journal of Colloidal and Interface Science, 293, 16-26. https://doi.org/10.1016/j.jcis.2005.06.021

[11] Raoufi, F., Monajjemi, M. and Aghaie, H. (2017) Adsorption of Thymol Blue and Erythrosine-B on MWCNTS Functionalized by N-(3-Nitrobenzylidene)-N'-Trimethoxysilylpropyl-Ethane-1, 2-Diamine Equilibrium, Kinetics and Thermodynamic 
Study. Oriental Journal of Chemistry, 33, 2542-2550.

https://doi.org/10.13005/ojc/330550

[12] Blais, J., Dufresne, S. and Mercier, G. (1999) State of Technological Development on the Removal of Metals from Industrial Effluents. Review of Water Sciences, 12, 687-711. https://doi.org/10.7202/705373ar

[13] Ndi, J.N. and Ketcha, J.M. (2013) The Adsorption Efficiency of Chemically Prepared Activated Carbon from Cola Nut Shells by $\mathrm{ZnCl}_{2}$ on Methylene Blue. Journal of Chemistry, 2013, 1-7. https://doi.org/10.1155/2013/469170

[14] Tchuifon, T.D.R., Anagho, S.G., Nche, G.N. and Ketcha, J.M. (2015) Adsorption of Salicylic and Sulfosalicylic Acid onto Powdered Activated Carbon Prepared from Rice and Coffee Husks. International Journal of Current Engineering and Technology, 5, 1641-1652.

[15] Ngakou, S.C., Ngomo, M.H. and Anagho, S.G. (2018) Batch Equilibrium and Effects of Ionic Strength on Kinetic Study of Adsorption of Phenacetin from Aqueous Solution Using Activated Carbon Derived from a Mixture of Ayous Sawdust and Cucurbitacea Peelings. Current Journal of Applied Science and Technology, 26, 1-24. https://doi.org/10.9734/CJAST/2018/37300

[16] Ajifack, D.L., Ghogomu, J.N., Ndi, J.N. and Ketcha, J.M. (2015) Dynamics and Equilibrium Studies of the Adsorption of Cu (II) from Aqueous Solutions by Activated Hibiscus sabdariffa. L. Stalk Biomass. International Journal of Engineering Research \& Technology, 4, 655-664. https://doi.org/10.9734/BJAST/2014/12742

[17] Idris-Hermann, K.T., Donald, R.T.T., Giscard, D. and Solomon G.A. (2018) Preparation and Characterization of Activated Carbons from Bitter Kola (Garcinia kola) Nut Shells by Chemical Activation Method Using $\mathrm{H}_{3} \mathrm{PO}_{4}$; $\mathrm{KOH}$ and $\mathrm{ZnCl}_{2}$. Chemical Science International Journal, 23, 1-15. https://doi.org/10.9734/CSJI/2018/43411

[18] Cazetta, A.L., Vargas, A.M.M., Nogami, E.M., Kunita, M.H., Guilherme, M.R., Martins, A.C., Silva, T.L., Moraes, J.C.G. and Almeida, V.C. (2011) NaOH-Activated Carbon of High Surface Area Produced from Coconut Shell: Kinetics and Equilibrium Studies from the Methylene Blue Adsorption. Chemical Engineering Journal, 174, 117-125. https://doi.org/10.1016/j.cej.2011.08.058

[19] Ustinov, E.A. and Do, D.D. (2002) Adsorption in Slit-Like Pores of Activated Carbons: Improvement of the Horvath and Kawazoe Method. Langmuir, 18, 4637-4647. https://doi.org/10.1021/la0105351

[20] Anagho, S.G., Ketcha, J.M., Tchuifon, T.D.R. and Ndi, J.N. (2013) Kinetic and Equilibrium Studies of the Adsorption of Mercury (II) Ions from Aqueous Solution Using Kaolinite and Metakaolinite Clays from Southern Cameroon. International Journal of Research in Chemistry and Environment, 3, 1-11.

[21] Ho, Y.S. and McKay, G. (1999) Pseudo-Second Order Model for Sorption Process. Process Biochemistry, 34, 451-465. https://doi.org/10.1016/S0032-9592(98)00112-5

[22] Weber, W.J. and Morris, J.C. (1963) Kinetics of Adsorption of Carbon from Solution. Journal of the Sanitary Engineering Division, American Society of Civil Engineering, 89, 31-60.

[23] Chien, S.H. and Clayton, W.R. (1980) Application of Elovich Equation to the Kinetics of Phosphate Release and Sorption in Soils. Soil Science Society of America Journal, 44, 265-268. https://doi.org/10.2136/sssaj1980.03615995004400020013x

[24] Dalal, R.C. (1974) Desorption of Soil Phosphate by Anion-Exchange Resin. Communications in Soil Science and Plant Analysis, 5, 531-538. https://doi.org/10.1080/00103627409366531 
[25] Avrami, M. (1940) Kinetics of Phase Change. II Transformation-Time Relations for Random Distribution of Nuclei. Journal of Chemical Physics, 8, 212-224. https://doi.org/10.1063/1.1750631

[26] Tobin, M.C. (1974) Theory of Phase Transition Kinetics with Growth Site Impingement. I. Homogeneous Nucleation. Journal of Polymer Science: Polymer Physics Edition, 12, 399-406. https://doi.org/10.1002/pol.1974.180120212

[27] Langmuir, I. (1916) The Constitution and Fundamental Properties of Solids and Liquids. Part I. Solids. Journal of the American Chemical Society, 38, 2221-2295. https://doi.org/10.1021/ja02268a002

[28] Freundlich, H.M.F. (1906) Over the Adsorption in Solution. Journal of Physical Chemistry, 57, 385-471.

[29] Tempkin, M.I. and Pyzhev, V. (1940) Kinetics of Ammonia Synthesis on Promoted Iron Catalyst. Acta Physicochimica URSS, 12, 327-356.

[30] Dubinin, M.M. and Radushkevich, L.V. (1947) Equation of the Characteristic Curve of Activated Charcoal. Proceedings of the Academy of Sciences of the USSR, Physical Chemistry Section, 55, 331-333.

[31] Elovich, S.Y. and Larinov, O.G. (1962) Theory of Adsorption from Solutions of Non-Electrolytes on Solid (I) Equation Adsorption from Solutions and the Analysis of Its Simplest Form, (II) Verification of the Equation of Adsorption Isotherm from Solutions. Izvestiya Akademii Nauk. SSSR, Otdelenie Khimicheskikh Nauk, 2, 209-216. https://doi.org/10.1007/BF00908017

[32] Jovanovic, D.S. (1969) Physical Adsorption of Gases I: Isotherms for Monolayer and Multilayer Adsorption. Colloid and Polymer Science, 235, 1203-1214. https://doi.org/10.1007/BF01542530

[33] Ayawei, N., Ebelegi, A.N. and Wankasi, D. (2017) Modelling and Interpretation of Adsorption Isotherms. Journal of Chemistry, 2017, 1-11. https://doi.org/10.1155/2017/3039817

[34] Hamdaoui, O. and Naffrechoux, E. (2007) Modeling of Adsorption Isotherms of Phenol and Chlorophenols onto Granular Activated Carbon Part II. Models with More than Two Parameters. Journal of Hazardous Materials, 147, 401-411. https://doi.org/10.1016/j.jhazmat.2007.01.023

[35] Mahdi, H., Mohammad, R., Samarghandi and McKay, G. (2010) Equilibrium Two-Parameter Isotherms of Acid Dyes Sorption by Activated Carbons: Study of Residual Errors. Chemical Engineering Journal, 160, 408-416. https://doi.org/10.1016/j.cej.2010.03.016

[36] Ozdemir, I.S., Sahin, M., Orhan, R. and Erdem, M. (2014) Preparation and Characterization of Activated Carbon from Grape Stalk by Zinc Chloride Activation. Fuel Processing Technology, 125, 200-206. https://doi.org/10.1016/j.fuproc.2014.04.002

[37] Yorgun, S., Vural, N. and Demiral, H. (2009) Preparation of High-Surface Area Activated Carbons from Paulownia Wood by $\mathrm{ZnCl}_{2}$ Activation. Microporous and Mesoporous Materials, 122, 189-194. https://doi.org/10.1016/j.micromeso.2009.02.032

[38] Chowdhury, S. and Saha, P. (2010) Sea Shell Powder as a New Adsorbent to Remove Basic Green 4 (Malachite Green) from Aqueous Solutions: Equilibrium, Kinetic and Thermodynamic Studies. Chemical Engineering Journal, 164, 168-177. https://doi.org/10.1016/j.cej.2010.08.050

[39] Hameed, K.S., Muthirulan, P. and Meenakshi, S.M. (2017) Adsorption of Chromotrope Dye onto Activated Carbons Obtained from the Seeds of Various Plants: Equilibrium and Kinetics Studies. Arabian Journal Chemistry, 10, S2225-S2233. 
https://doi.org/10.1016/j.arabjc.2013.07.058

[40] Alberghina, G., Bianchini, R., Fichera, M. and Fisichella, S. (2000) Dimerization of Cibacron Blue $\mathrm{F}_{3} \mathrm{GA}$ and Other Dyes: Influence of Salts and Temperature. Dyes and Pigments, 46, 129-137. https://doi.org/10.1016/S0143-7208(00)00045-0

[41] Calvete, T., Lima, E.C., Cardoso, N.F., Vaghetti, J.C., Dias, S.L. and Pavan, F.A. (2010) Application of Carbon Adsorbents Prepared from Brazilian-Pine Fruit Shell for the Removal of Reactive Orange 16 from Aqueous Solution: Kinetic, Equilibrium, and Thermodynamic Studies. Journal of Environmental Management, 91, 1695-1706. https://doi.org/10.1016/j.jenvman.2010.03.013

[42] Zhou, Z., Lin, S., Yue, T. and Lee, T. (2014) Adsorption of Food Dyes from Aqueous Solution by Glutaraldehyde Cross-Linked Magnetic Chitosan Nanoparticles. Journal of Food Engineering, 126, 133-141.

https://doi.org/10.1016/j.jfoodeng.2013.11.014 